\title{
WORKER PARTIGIPATION IN SWEDEN AND THE UNITED STATES: SOME GOMPARISONS FROM AN AMERICAN PERSPECTIVE
}

\section{Clyde Summers $\dagger$}

The first question that must be confronted in a comparative study is: what is the purpose of making a comparison? Quite different purposes may be served, some more useful or more ambitious than others, but the purposes sought to be achieved inevitably shape the manner in which the comparison is made.

In labor law and labor relations one of the most helpful uses of comparison is to provide a broader perspective from which we can critically examine our own legal rules and institutional practices. By studying the Swedish system, a working and reasonably successful system, we may recognize that legal rules and principles we in the United States have unquestionably accepted as fundamental are not essential, for Sweden functions and prospers with quite different rules. We may recognize that certain of our practices and institutions in union-management relations are more products of historical events and perpetuated by habit than compelled by economic forces or adopted as social choices. At the same time we may realize that legal rules and institutional structures are interrelated in ways we had not suspected and that particular rules have social consequences we have not considered. The comparative perspective helps us to see through the myths of our own system, to uncover the hidden premises on which we build, and to see more clearly the realities of our system and its special characteristics.

Comparison that leads to greater self-understanding can suggest constructive changes, changes otherwise unthought or even unthinkable. When hidden premises are examined critically and accepted principles are questioned skeptically, we can see the need and potential for change. Examining another system opens our minds to other premises and forces our imagination to find new forms and devices to meet newly felt needs. We cannot, of course, blindly borrow from another system; that which works well in Sweden will not necessarily work well in the United States. Awareness of the differences between the two sys-

$\dagger$ Jefferson B. Fordham Professor of Law, University of Pennsylvania. B.S. 1939, J.D. 1942, University of Illinois; LL.M. 1946, J.S.D. 1952, Columbia University. Member New York Bar. The University of Pennsylvania Law Review has not verified the content of the Swedish sources cited in this Article. 
tems warns against such simplistic copying or piecemeal transplanting of legal rules. But that same awareness of differences can instruct us in shaping solutions that are suitable to our own system.

Labor law, more than many other areas of law, is the product of conscious creation and social choice. Our basic labor statutes were not products of an evolutionary process but were deliberately designed as instruments of change. They declared new social policies and established new legal principles to meet newly felt needs. Some, like the Wagner Act, ${ }^{1}$ the Landrum-Griffin Act, ${ }^{2}$ and Title VII of the Civil Rights $\mathrm{Act}^{3}$ were American inventions that provided ideas for changes in other countries. Others, such as workman's compensation, unemployment insurance, and much safety and protective legislation, drew on principles and rules found in earlier European legislation. Current proposals concerning plant closures, unjust dismissal, work groups, and employee representation on corporate boards are inspired or reinforced by foreign experience. We can learn much more about where we are and what directions we might take by comparisons with other systems.

The comparison here is between "worker participation" in Sweden and the United States. "Worker participation" is used in a broad sense to include all those structures and processes through which employees have a voice in the decisions of the enterprise that affect their working lives, from negotiation of national agreements to consultation of work groups on the shop floor. "Industrial democracy" or "codetermination" might also be used, although these terms are sometimes used with broader or narrower meanings. Comparison here is limited to the private sector; comparison in the public sector would require a different framework of analysis because American law draws basic distinctions between the two sectors.

The reasons for focusing on this aspect of labor law are two-fold. First, studying worker participation requires us to examine the central principles of labor law and the processes of decision-making by labor market institutions. It therefore provides a good vantage point for viewing labor law and industrial relations systems generally. A second reason for focusing on worker participation is that, in my view, increasing worker participation was one of the original purposes of the Wagner Act, is one of the central functions of collective bargaining, and should be a major social goal of labor law. It has also been one of the central goals of the Swedish labor movement and has been given concrete ex-

1 National Labor Relations Act, 29 U.S.C. §§ 151-169 (1982).

2 Labor-Management Reporting and Disclosure Act of 1959, 29 U.S.C. §§ 401531 (1982).

${ }^{3}$ Civil Rights Act of 1964, 42 U.S.C. $§ 2000$ e (1982). 
pression in the 1976 Act on Codetermination at Work ${ }^{4}$ [the MBL]. To obtain a clearer understanding in both Sweden and the United States as to the methods by which this goal may be achieved and the effectiveness of each system in achieving it, it is useful to ask to what extent and in what way do the Swedish and American systems of labor relations and labor law provide employees with the ability to participate in the decisions that affect their working lives?

Any attempt to make such a comparison is a risky undertaking, for inevitably I see the Swedish system from an American perspective, burdened by unconscious American assumptions. It is obviously impossible for one who has not lived and worked within an industrial relations system to have a full understanding of the complexities and nuances of that system. Because of incomplete knowledge, relevant considerations may be overlooked or misconstrued. More important, deep-running social attitudes, political values, or historical traditions may not be fully or accurately sensed. The comparative study itself sharpens our awareness of these dangers. As one realizes how much he has failed to understand his own system, he must fear that he has failed to understand the other. But the value of comparison remains, for comparison provides a framework and focus outside either system for viewing both.

\section{Some Basic Similarities}

When one first examines the central legal principles and institutional structures of worker participation in the United States and Sweden, one is struck by certain basic similarities. This is particularly true when one compares them with, for example, the German system. ${ }^{5}$

First, participation in both the United States and Sweden is based on the legal principle of freedom of choice of employees. Section 7 of the National Labor Relations Act," enacted in 1935, declares, "Employees shall have the right to form, join or assist labor organizations, [and] to bargain through representatives of their own choosing."' Section 3 of the Swedish Act on the Right of Association and Negotiation, ${ }^{8}$

4 Lag om Medbestämmande $\mathrm{i}$ arbetslivet, den 10 juni 1976 (Act on the Joint Regulation of Working Life) [hereinafter cited as MBL], translated in F. ScHMIDT, LaW and Industrial Relations In SWEDEN 234-46 (1977). See Victorin, Co-determination in Sweden: The Union Way, 2 J. Comp. Corp. L. \& SEC. REg. 111, 116-27 (1979).

5 See Summers, Worker Participation in the U.S. and West Germany: A Comparative Study from an American Perspective, 28 AM. J. Comp. L. 367 (1980).

b 29 U.S.C. $\$ \S 151.69$ (1982).

I Id. $\S 157$.

8 Lag om Förennngsöch förhandlingsrätt den 11 September 1936 (Act Respecting the Right of Association and the Right of Collective Bargaining), translated in $\mathrm{F}$. 
enacted the following year, declares, "The right of association shall not be infringed, and an association shall not be bound to tolerate any infringement of the right of association which constitutes interference with its activities." and has different legal and practical contours in the two countries, ${ }^{10}$ it is a common dominant principle.

In both countries participation is through collective negotiations; whether there are to be collective negotiations and what union is to act as representative, in principle, depends on the free choice of the employees. Further, selection of those who are to serve as negotiators is through union procedures determined by union members. ${ }^{11}$ This contrasts with the German system, which legally establishes work councils, requires that one be created in each workshop of more than five employees, and prescribes its make-up and functions. ${ }^{12}$

Second, in both the United States and Sweden participation at all levels is through the union, and representation at the enterprise or plant level is tied closely to the union that makes the collective agreement. In the United States the majority union is the exclusive representative for purposes of negotiating collective agreements, and the employer is prohibited by law from negotiating with anyone other than the majority union on matters concerning "rates of pay, wages, hours of employment, [and] other conditions of employment."13 In addition, most collective agreements give the contracting union exclusive control over grievances arising under the agreement. ${ }^{14}$ In Sweden collective

Schmidt, The Law of Labour Relations in Sweden 251-58 (1962).

${ }^{9} \mathrm{Lag}$ om Förennngsö̈ch förhandlingsrätt den 11 September 1936 (Act Respecting the Right of Association and the Right of Collective Bargaining), translated in F. SCHMIDT, supra note 4 , at 251 . This protection was carried over in $\$ \S 7-9$ of the MBL in 1976. See id. at 235.

${ }^{10}$ See Summers, Freedom of Association and Compulsory Unionism in Sweden and the United States, 112 U. PA. L. REv. 647 (1964).

11 See General Elec. Co. v. NLRB, 412 F.2d 512, 516 (2d Cir. 1969)("[T]he right of employees . . . to choose whomever they wish to represent them in formal labor negotiations is fundamental to the statutory scheme.")

12 Betriebsverfassungsgesetz (1972). See also M. Peltzzer, BetriebsverfasSUngsgesetz, Labor Management Relations ACt 15-38, 147-70 (2d ed. 1977). See generally M. WeIss, BETRIEBSVERfassungsgeseTZ, EIN KOMMENTAR FÜR STUDIUM UND PRAXIS (1978).

13 National Labor Relations Act $\S 9$ (a), 29 U.S.C. $\$ 159$ (a) (1982). See also J.I. Case Co. v. NLRB, 321 U.S. 332, 338-39 (1944) (individual contracts are pushed aside once union becomes exclusive bargaining representative); Order of R.R. Telegraphers v. Railway Express Agency, Inc., 321 U.S. 342, 346-47 (1944) (under Railway Labor Act of 1926, company may not negotiate individual contracts without first approaching employees' exclusive bargaining representative).

${ }_{14}$ See, e.g., Emporium Capwell Co. v. Western Addition Community Org., 420 U.S. 50, 69-70 (1975); cf. J.I. Case Co. v. NLRB, 321 U.S. 332, 337 (1944) (collective agreement supercedes terms of individual contracts); Medo Photo Supply Corp. v. 
agreements are negotiated by national unions on an industry-wide basis, ${ }^{16}$ and under the 1976 Codetermination $\mathrm{Act}^{16}$ [MBL] the legal right to codetermine at the enterprise level runs almost exclusively to unions that have collective agreements. ${ }^{17}$ The only exception occurs when the problem involves only individuals belonging to another union. ${ }^{18}$ In neither country is there a dual structure, as in Germany, where wages and other economic terms are negotiated by the union in a national or area agreement while decisions at the enterprise and plant level are negotiated or decided by works councils that are not a part of the union but are created by statute and are legally independent of the union. ${ }^{10}$

Third, in both the United States and Sweden, the effectiveness of the employees' voice in decisions of the enterprise depends in the first instance on negotiation, but depends ultimately on economic force. Whether the employees' voice will be heard and prevail depends on the union's ability to persuade the employer, either at the bargaining table or by the economic pressure of a strike. In the United States all matters are generally settled in the same negotiations, with a comprehensive collective agreement determining not only wages and other economic terms, but also the limits on management prerogatives. The strike is available to resolve all of these issues when the collective agreement is made. Although the collective agreement normally includes a no-strike clause, the parties may limit the contractual no-strike obligation to permit certain disputes, such as those over safety and production standards, to be resolved by strikes during the contract term. In Sweden collective agreements have historically been limited to wages and other economic terms, but the 1976 statute contemplated that these negotiations might be enlarged to include "codetermination subjects," or the negotiation of a general "codetermination agreement" providing for union participation in management decisions, with the strike available

NLRB, 321 U.S. 678, 684 (1944) (negotiations directly with employees rather than with union is unfair labor practice).

15 See T. Johnston, Collective Bargaining in Sweden 235-36 (1962); Elvander, Sweden, in Towards Industrial DEMocracy 133-34 (B. Roberts ed. 1979).

$18 \mathrm{MBL}$, translated in F. SCHMIDT, supra note 4, at 234-46.

17 MBL $\S \S 11,12,32,34,35,38$. Section 11, for example, provides, "Before an employer decides an important alteration to his activity, he shall, on his own initiative, negotiate with an organisation of employees in relation to which he is bound by collective agreement." F. SCHMIDT, supra note 4, at 235.

18 See MBL $\S 13$, translated in F.SchMIDT, supra note 4, at 236. In that case the employer is required to negotiate with the union to which the particular employees belong. The duty is the same as that owed to a union with a collective agreement.

19 See Leminsky, Worker Participation: The German Experience, in LABOR RELations in Advanced Industrial Societies: Issues and Problems 146-49 (1980); Summers, supra note 5, at 373-74. 
to resolve all of these issues. ${ }^{20}$ Even though a collective agreement on economic terms is signed, creating a statutory no-strike obligation, the union may reserve the right to strike during the contract term on codetermination issues not resolved by the agreement. ${ }^{2 I}$

Again, this contrasts with the German system, under which the works council has the right to negotiate on a wide range of matters but has no right to strike. However, on many matters of the greatest importance, if no agreement is reached, the dispute is resolved through binding arbitration by a neutral person. ${ }^{22}$

In spite of the legal similarities between the Swedish and American systems, even a casual familiarity with the practical operation of the two makes one aware that they are quite different. To make any meaningful comparison, it is necessary to go beyond these broadly stated legal principles. The legal rules may be less similar than they first appear, and even parallel legal rules may have quite different practical consequences in different institutional settings. Other less apparently relevant legal rules may intervene, and the law may be less important than social and economic factors.

\section{Some Significant Contrasts}

For the purpose of helping us see our own system more clearly, contrasts in the practical operation of the two systems may be more revealing than the similarities in their legal rules. Contrasts provoke questions as to reasons for the differences, and a search for those reasons may lead to new insights and clearer understandings. The focus here is on two significant contrasts: differences in the completeness of coverage and in the centralization of the two systems.

\section{A. Completeness of Coverage}

The most marked and probably most significant factor distinguishing the practical operation of the two systems is the extent to which

${ }^{20}$ See Victorin, supra note 4, at 118-27. The term codetermination subjects refers here to those areas of industrial relations or subjects for negotiation embraced by the MBL that were not customarily dealt with by collective agreements on wages and other economic terms prior to the passage of the MBL. The term codetermination agreement refers to those agreements negotiated under $\$ 32$ of the MBL.

${ }_{21}$ See MBL $\S 44$, translated in F. ScHMIDT, supra note 4, at 241-42. It is uncertain whether the union could, by express provision in the collective agreement, preserve the right to strike on all codetermination issues, regardless of whether they were specifically mentioned during negotiations or whether it is necessary that the specific matters be raised in the negotiations.

${ }_{22}$ Betriebsverfassungsgesetz, $\S \S 76,87,91,94,95,98,109,112$; see also $M$. Peltzer, supra note 12, at 153-58. 
they cover all employees in the labor market. In Sweden ninety-five percent of all blue-collar workers and seventy-five percent of all salaried employees are members of unions, and almost every employer in every branch of the economy is covered by a collective agreement. ${ }^{23}$ As a result, almost every employee in Sweden is included in the participation system; coverage is, for practical purposes, complete. ${ }^{24}$ In the United States fewer than twenty-five percent of those in the employed work force are union members, ${ }^{25}$ and fewer than thirty percent are covered by collective agreements. ${ }^{26}$ This means that in the United States seventy percent of the employees in the labor market have no collective voice, either in determining their terms and conditions of employment or in influencing the decisions of the enterprises in which they work.

This incomplete coverage in the United States reflects in part the operation of the basic legal principle of freedom of choice, subject to majority rule. Whether there is to be collective bargaining and which union is to act as representative are decided by the majority of the employees in the bargaining unit. ${ }^{27}$ Those bargaining units, whether determined by the National Labor Relations Board or by agreements of the parties, typically are relatively small. Most units are limited to a single employer and are commonly confined to a single plant or workplace. ${ }^{28}$ Even within a single plant, separate units will often exist for blue-collar workers and white-collar workers and for special craft and

${ }^{23}$ See L. Forsebäck, Industrial Relations and Employment in Sweden 30 (1976). Most blue-collar workers are organized in national unions affiliated with the Swedish Confederation of Trade Unions (Landsorganisationen i Sverige, or LO). Most white-collar workers are organized in national unions affiliated with either the Central Organization of Salaried Employees (TCO) or the Confederation of Professional Associations (SACO/SR). There are only a few small unions outside these federations. See F. ScHMrDT, supra note 4, at 17-20; Victorin, supra note 4, at 111-12.

${ }^{24}$ Section 26 of the MBL provides that the collective agreement is binding on the members of the employers' association and the union concluding the agreement. $F$. SCHMIDT, supra note 4, at 238. An employer is bound regardless of how many of his employees are members of the union, and he is obligated to apply the agreement to employees who are not members of the union unless the agreement expressly provides otherwise. See F. SchMIDT, LöNTAGARRäTT 39-40 (1978). The practical effect is that collective agreements cover all of the employees of members of the employers' association, whether or not they are union members.

${ }^{25}$ Directory of U.S. Labor Organizations: 1982-83 Edition 1 (C. Gifford ed. 1982).

${ }^{28}$ Bureau of Labor Statistics, U.S. Dep't of Labor, Bull. No. 2079, DiRECTORY OF NATIONAL LABOR UNIONS AND EMPLOYEe Associations, 1979 at 59, 73-74 (1980) [hereinafter cited as Directory of NATIONAL LABOR Unions].

27 National Labor Relations Act, 29 U.S.C. \& 159 (1982).

${ }^{28}$ In 1978 there were more than 175,000 collective agreements covering a total of approximately 25 million employees. DiREctory of National Labor Unions, supra note 26, at 74. In 1980 the average number of voters in the units in which the NLRB held elections was 56 . Three-fourths of all units had fewer than 59 voters. 45 NLRB ANN. REP. 18 (1980). 
professional employees. ${ }^{29}$ The coverage of collective agreements is incomplete because in the great majority of workplaces a union is not able to show the thirty percent support among the employees that is necessary to obtain an election; and even when unions show sufficient support, they lose more than half of the elections. ${ }^{30}$

Sweden, also starting with the legal principle of freedom of choice-but one not qualified by majority rule ${ }^{31}$ - ends with a collective bargaining system that covers practically all employees. Completeness of coverage in Sweden cannot be explained, however, by the lack of the majority rule principle. This factor-employees signing agreements when only a minority of employees are members - is of only marginal importance in bringing employees within the collective bargaining system. Nor can the completeness of coverage be explained by other legal rules. Indeed, if the Swedish legal rules and enforcement methods were transplanted to the United States, the level of unionization here would, in all probability, be even lower. The explanation lies in two nonlegal factors.

First, the plainly observable fact is that in Sweden an overwhelming majority of workers choose to join unions and support collective bargaining, whereas in the United States a majority refuse to join unions and, instead, vote to reject collective bargaining. How can we explain this great difference in the two countries? Partial explanations may be found in cultural attitudes toward joining organizations, collective action, and social responsibility, but these seem inadequate to explain the magnitude of the difference.

The second and more crucial factor determining the level of unionization and collective bargaining is, in my view, the attitudes and practices of employers. In the United States the major cause of the low level of unionization is the hostility of employers to unions and their efforts to defeat collective bargaining. Some employers systematically and deliberately violate the law, using repressive and coercive actions that effectively deprive employees of any freedom of choice. ${ }^{32}$ They are pre-

29 See generally J. Abodeely, R. HAmmer \& A. SANDler, The NLRB and THE APPRopriate Bargaining UnIT (rev. ed. 1981) (discussing criteria used by NLRB to determine the appropriate bargaining unit).

so 45 NLRB ANN. REP. 16 (1980).

31 A Swedish employer, unlike an American employer, can legally sign a collective agreement that effectively governs all of his employees even though only a few or even none of them are members of the union. F. ScHmIDr, supra note 4, at 102, 123.

32 A brief sketch of one employer's repeated violations can be found in NLRB v. J.P. Stevens \& Co., 563 F.2d 8, 25 (2d Cir. 1977), described by the court as "Stevens XVIII in the long list of Stevens litigation." See also Kovach, J.P. Stevens and the Struggle for Union Organization, 29 LAB. L.J. 300, 308 (1978) (during fourteen-year period, NLRB found Stevens guilty of unfair labor practices in fifteen separate cases 
pared to violate the law in order to prevent unionization in spite of legal sanctions that, by Swedish standards, are quite severe. ${ }^{33}$ Although the majority of employers stay within the limits of the law, they will go to its very boundaries to persuade employees not to join unions and to reject collective bargaining. When a collective bargaining election is scheduled, the employer will mount a massive publicity campaign, hold meetings of employees during work time, send letters to the employees' spouses, and organize community pressures to defeat the union in the election. ${ }^{34}$

Both of the major employers' organizations-the National Association of Manufacturers and the Chamber of Commerce-are openly and actively anti-union, sponsoring conferences, training sessions, and consulting services for employers for the declared purpose of preserving or reclaiming the union free environment. ${ }^{35}$ These programs and activities are endorsed and supported by employers who have had established collective bargaining relationships for more than forty years.

The contrast between these attitudes and practices of American employers and those of Swedish employers need not be elaborated upon. It would be a rare employer in Sweden who would try to discourage its employees from joining a union or persuade them that they would be better off without collective bargaining. And such an employer would be considered a pariah by other employers.

The attitudes of employers directly affect the readiness of employees to join unions because employees are subject to subtle fear, a sense of subservience, and appeals to loyalty. In addition, the dominant attitudes of employers are reflected in the public press, political debate, and discussions at all levels. These attitudes significantly shape, if not determine, the general social attitudes toward unions and collective

and awarded over $\$ 1.3$ million in back pay).

${ }^{33}$ When employees are discriminated against because of union membership or activity, the standard remedy is reinstatement with back pay. In 1980 the NLRB awarded $\$ 32.1$ million of back pay to 15,566 workers. In addition, 10,033 workers were offered reinstatement. Other violations are subject to cease and desist orders, and repeated violations may be punished as contempt of court. 45 NLRB ANN. REP. 13 (1980). In Sweden back pay awards have been few and small. Although fines can be levied, prior to 1976 these were nominal. Under the MBL, damages awarded for an employer's failure to negotiate have, in some cases, been very large.

${ }^{34}$ For a description of these tactics, see Oversight Hearings on the National Labor Relations Act: Hearings Before the Subcomm. on Labor-Management Relations of the House Comm. on Education and Labor on H.R. 8408, H.R. 8409, H.R. 8110 and H.R. 12822, 94th Cong., 2d Sess. 1 (1976) (statement of Stephen I. Schlossberg, General Counsel, United Auto Workers).

${ }^{35}$ See Pressures in Today's Workplace, Oversight Hearings Before the Subcomm. on Labor-Management Relations of the Comm. on Education and Labor, 96th Cong., 1st Sess. (1979) (statement of Robert A. Georgine). 
bargaining.

I would suggest that the high level of union membership in Sweden is due to a broad social consensus that collective bargaining is the appropriate method for managing the labor market. Critical to that consensus is the employers' acceptance of collective bargaining. There is no such acceptance of collective bargaining by American employers, but rather an open and active hostility to unions. This has created a social climate that discourages employees from joining unions. This difference in social consensus, made possible because of employer attitudes, largely explains the difference in the completeness of coverage of worker participation processes.

This only pushes our inquiry back another step, for we must now ask why the attitudes of Swedish employers are so different from employers in the United States. History suggests a partial answer.

Sweden, at the turn of the century, had its share of bitter strikes, and many Swedish employers discharged union members, locked out employees until they abandoned their union, or refused to bargain collectively. ${ }^{\text {se }}$ In 1906, in the face of continuing conflict, the Swedish Employers Confederation (SAF) and the Confederation of Swedish Trade Unions (LO) worked out the so-called December Compromise, ${ }^{37}$ which shaped Swedish labor relations for seventy years. ${ }^{38}$

The Compromise took the form of an agreement between the parties that the following provision would be included in every collective agreement between member associations of SAF and LO:

Reserving the observance of other rules in the agreement, the employer is entitled to direct and distribute the work, to hire and dismiss workers at will, and not to employ workers whether they are organized or not.

The right of association shall be left inviolate on both sides.

If the workers are of opinion [sic] that a dismissal has taken place in circumstances which can be interpreted as an attack upon the right of association, they may, before further steps are taken, call, through their organization, for an in-

36 See generally C. HALlENDORFF, SVENSKa ARBETSGIFVAREFöRENINGEN, 19021927, at 9-12 (1927); T. JohnSTON, supra note 15, at 124; T. LINDBOM, DEN SVENSKA FACKFÖRENINGSRÖRELSENS UPPKOMST, OCH TIDIGARE HISTORIA 1872-1900, at 168-73 (1938).

st The December Compromise of 1906, translated in F. ScHMIDT, supra note 8, at $26-27$.

s8 See generally A. Adlercreutz, Kollektivavtalet, Studier öVer Dess TILlkomsthistoria 344-48 (1954); C. HAllendORFF, supra note 36, at 79-83. 
vestigation for the vindication of their rights. ${ }^{39}$

One-half of the Compromise was the employers' explicit acceptance of unions and collective bargaining. The organized employers, in both symbolic and practical terms, placed their stamp of approval on unions and promoted the extension of collective bargaining. ${ }^{40}$ SAF refused to support employers who had not allowed their employees to join unions. ${ }^{41}$ More important, it negotiated agreements that covered workers who previously had not been organized. National agreements were negotiated in industries that were only partially organized, and those agreements covered employers in which only a minority of employees were union members.

Acceptance of collective bargaining did not represent capitulation by the employers. The other side of the Compromise was acceptance by the unions that there would be included in all collective agreements paragraph 23 (later paragraph 32) of the SAF statutes, which had been included in the December Compromise, providing that "the employer is entitled to direct and distribute the work, to hire and dismiss workers at will, and to employ workers whether they are organized or not." ${ }^{32}$ The employer thereby retained full control over decisions about who should be assigned to what work, who should be promoted and transferred, who was to be laid off or discharged, and how work was to be assigned and performed. ${ }^{43}$

With the December Compromise, organized employers approved unions and collective bargaining, discouraged anti-union practices, and extended the reach of collective agreements. The employers thus made possible and encouraged the growth of Swedish unions, and they ultimately helped create the social consensus that workers should join unions. In return, unions agreed to limit collective bargaining to wages, hours, and other economic terms. They gave up their claims to

38 The December Compromise of 1906, translated in F. Schmid, supra note 8, at $26-27$.

to J. Westerstahl, Svensk FackföReningsRörelse 150 (1945). The December Compromise did not represent a reversal of the policy of SAF. It had in fact accepted collective bargaining as unavoidable and rejected policies and practices of trying to destroy unions by violations of freedom of association. C. HALLENDORFF, supra note 36 , at $31,41,57,74$.

41 T. Bresky, J. Scherman \& I. Schmid, Med SAF vid Rodret: GransknING AV EN KAMPORGANISATION 34 (1981). at 26.

${ }^{42}$ The December Compromise of 1906, translated in F. ScHMIDT, supra note 8 ,

13 B. SChiller, LO, PARAgRAF 32 OCH FÖRETAGSDEMOKRATIN (1974). For a discussion of the impact of paragraph 32 on Labor Court decisions giving employers the right to make decisions concerning working conditions and control over the workplace and employees, see Victorin, supra note 4 at 119-20. 
codetermination on other matters, even those of great importance to employees, such as assignment of work and dismissal. Employers agreed to accept unions when the unions agreed not to interfere with management of the enterprise.

This pairing of a limitation on the role of unions with a recognition of management's prerogatives has been a dominant characteristic of the Swedish model of labor relations. It was a precondition and unspoken assumption of the famous Basic Agreement of $1938^{44}$ between SAF and LO, which laid down guidelines for union-employer relations, prescribed rules for economic conflict, and provided the framework for forty years of labor peace. ${ }^{45}$ Article III of the Agreement required the employer to notify the union of planned dismissals and allowed the union to call for negotiations and for investigation by the Labor Market Board. The ultimate right of decision, however, rested with the employer. The Works Council Agreements of 1946 and 1966 between the employer and union confederations, which set up "joint enterprise councils" to promote industrial democracy, superceded the Basic Agreement's provisions regarding dismissal and laying off of workers. They provided only for information and consultation; the right of decision remained with the employer. ${ }^{46}$

The single significant encroachment on paragraph 32, prior to the 1970's, was the 1964 amendment to the Basic Agreement, which limited the employer's right to discharge individual employees and provided for binding arbitration on the issue of whether the employer had "material grounds" for discharge. ${ }^{.7}$ Although LO continuously argued for industrial democracy during this period and repeatedly made demands to limit or do away with paragraph 32 , there was no willingness to use industrial action to curb management prerogatives. ${ }^{48}$ The unions

44 Basic Agreement Between the Swedish Employers' Confederation and the Confederation of Swedish Trade Unions, dated 20 December 1938, as amended in 1947, translated in F. SCHMIDT, supra note 4, at 263-77.

48 B. SCHILlER, supra note 43 , at 54-64.

46 T. BRESKy, J. SCherMan \& I. SCHMID, supra note 41, at 73; B. SCHILleR, supra note 43 , at 65-71, 87-88. The weakness and ineffectiveness of works councils were emphasized by LO in LO, Industrial Democracy, Programme Adopted by THE 1971 LO Gongress 241, and in CO-DETERMINATION ON THE Foundation of Solidarity, A Report to THE 1976 Congress of the Swedish Trade Union CONFEDERATION, at 60, in which it was said that "works councils in their present form have come to the end of their usefulness."

${ }^{47}$ Huvudavtalet (Basic Agreement), Kap. III, § 4. This was negotiated as a part of the central wage negotiations, the only occasion on which the unions attempted to negotiate any limitation on paragraph 32, although paragraph 32 was included in collective agreements on wages.

48 See, e.g., Demokrati I Företagen, RAPPORT TILl LO-KONGRESSEN (1972); LO, FACKFöreningSRörelsen OCH Näringslivet 177-83 (1941); B. Schiller, supra note 43 , at $37-53$. 
accepted, however grudgingly, the employer's right to decide matters outside the economic terms regulated by the collective agreement. ${ }^{49}$

In sharp contrast, American unions have never conceded to employers such prerogatives. From their earliest days unions have demanded and struck for contractual provisions requiring employees to be union members, thereby limiting the employer's freedom to choose workers. ${ }^{\text {so }}$ Collective agreements have customarily prescribed the categories of employees to be used to perform certain work, limited the kind of work an employee could be required or permitted to do according to the employee's job classification, and regulated the number of employees to be used in certain operations. Unions have insisted on regulating job assignments, the transfer of employees, and promotions, and few unions would sign an agreement that lacked either a seniority clause regulating lay-offs and rehires or a clause prohibiting discharge without just cause. ${ }^{k 1}$ Unions have engaged in bitter and protracted strikes to obtain these provisions and many others that limit management control. ${ }^{52}$

I would suggest that one of the reasons American employers have resisted unions in ways that Swedish employers have not is that American unions have never accepted the limitations of paragraph 32. American employers have viewed the union as a threat to their control over management of the enterprise, a threat that Swedish employers have not felt-or hadn't until the 1970's. One reason collective bargaining covers only a minority of workers in the United States is that unions have insisted on substantial limitations on management prerogatives. Coverage in Sweden is nearly complete in part because unions, for sev-

48 B. SCHILleR, supra note 43 , at $52-53$.

so See, e.g., Commonwealth v. Hunt, 45 Mass. (4 Met.) 111 (1842) (allowing union to enforce closed shop to compel compliance with union pay scale); Gray v. Building Trades Council, 91 Minn. 171, 97 N.W. 663 (1903) (members of trades council may legally refuse to work with nonunion employees); National Protective Ass'n v. Cumming, 170 N.Y. 315, 63 N.E. 369 (1902) (no cause of action exists for employee dismissed by employer under pressure from union seeking closed shop); J. Commons, Trade Unionism and Labor Problems 54-56, 94-95 (1905). Early collective agreements established lines of promotions for butchers, id. at 233-34, and the printers union insisted that only printers should operate linotype machines, $i d$. at 26970.

ol See S. Slichter, J. Healy \& E. Livernash, The Impact of Collective Bargaining on Management (1960).

${ }^{62}$. On the railroads, repeated disputes, some leading to strikes and some to legislative resolution, have arisen over the number of persons required to operate diesel locomotives. Dock workers closed down shipping on the whole East Coast to prevent or regulate the use of containers in loading ships. Steelworkers struck for months to preserve work rules that limit management's discretion in assigning work and determining the number of employees on work crews. Auto workers reserve the right to strike concerning production standards and the speed of assembly lines, and they exercise it. 
enty years, did not challenge management control and thereby gained employer acceptance and social support for collective bargaining.

Other reasons undoubtedly help to explain the difference in employers' attitudes toward unions in the United States and Sweden. One is the lack of strong employers associations in the United States. In Sweden almost all employers in the private sector are members of the Swedish Employers Confederation and its national industry association. ${ }^{53}$ These associations bargain on a national level and establish national wage patterns. ${ }^{\text {s4 }}$ In the United States there is no equivalent national employers association, and there are only a limited number of employers associations that blanket a competitive market. The result is that American employers know that any concessions that they make to a union will not necessarily be matched by their competitors. Employers associations that cover various labor markets could help to dispel employers' fears of wage competition from other employers.

Even when an industry is fully unionized, employers still prefer to operate nonunion and continue to be hostile to union limitations on management control. It is worth noting that as the SAF was being formed in Sweden, the National Metal Trades Association and the National Association of Manufacturers Associations were formed in the United States, but the latter promoted the "open shop" campaign that urged denying employees freedom of association and rejecting collective bargaining. ${ }^{58}$ The central goal of their program was to protect the right of employers to hire and dismiss workers and to manage the work force free of union control. In the United States national employers organizations have been among the most active and outspoken opponents of unions and collective bargaining.

\section{B. Centralization}

The second marked difference between the Swedish and American systems is their degree of centralization. The Swedish system of collective bargaining has been noted for its centralization, with national industry agreements negotiated between national unions and national em-

s3 SAF has more than 37,000 members employing over $1,300,000$ employees. SVENSKA ARBETSGTVAREFöRENINGENS VERKSAMHET (1980). Independent employers' associations cover cooperatives, banks, newspapers, and shipping. Provincial and local governments are also represented by employers' associations. F. ScHMIDT, supra note 4 , at $21-22$.

ot See T. Johnston, supra note 15 , at 78 .

Bs See generally C. BONNETT, EMPLOYERS' Associations IN THE UNITED States: A Study of Typical. Associations (1922); R. Hoxie, Trade Unionism IN THE UNITED States 188-210 (1923); D. Lescohier \& E. BrandeIs, History of LABOR IN THE UNITED STATES, 1896-1932, at 274-302 (1935). 
ployers associations. Since the 1950's these have been negotiated within the framework of master agreements negotiated between the union confederations and the employers' confederations covering almost the entire private sector. ${ }^{56}$ In contrast, the American system is noted for its decentralization, with collective agreements typically being negotiated on a plant or enterprise level. The union structure in each country tends to match the bargaining structure. Swedish unions are highly centralized, with plant organizations weak or nonexistent; American unions are relatively decentralized, with local unions playing a significant and often autonomous role.

Decentralization in the United States is rooted in part in the legal principle of employee free choice and in the way it operates in American labor relations. In the words of section 7 of the National Labor Relations Act, employees have the "right to bargain collectively through representatives of their own choosing." choice, subject to majority rule, the election or bargaining units are relatively small, often splitting a single enterprise into a number of units.

The model on which the law is built-and the dominant pattern in practice-is that each unit bargains separately, with the local union negotiating its collective agreement and handling the grievances of employees in the unit. This is often done with little or no supervision or control by the national union.

Although the law is a decentralizing force, it does not compel decentralization, for the law allows the parties to combine election units into larger bargaining units, and they often do. ${ }^{58}$ General Motors has more than a hundred plants, with each plant potentially a separate unit. But in most plants the auto workers union is the majority union for the blue-collar workers, and it negotiates a central agreement covering all those units in which it is the bargaining representative. The steelworkers union bargains centrally with all of the major steel companies, and the teamsters union negotiates a National Master Freight Agreement with an employers association covering hundreds of trucking companies in over-the-road hauling. But even when there is a central agreement, local agreements often exist on matters that require local adaptation or do not require national uniformity. ${ }^{58}$

victorin, supra note 4, at 111-12. In the negotiations in April of 1983, this process fractured as the largest union, the Metalworkers, broke ranks and concluded a separate pay agreement with higher productivity-linked pay. See infra note 65.

s7 29 U.S.C. § 157 (1982). 1961).

s8 See generally The Structure of Collective Bargaining (A. Weber ed.

so Livernash, Special and Local Negotiations in Frontrers of Collecrive Bargaining 27, 27-49 (J. Dunlop \& N. Chamberlain eds. 1967). 
Centralization in Sweden also has a taproot in the law-the legality of the sympathetic lockout. ${ }^{\text {Bo }}$ The tactic of SAF and its member associations has always been to expand local or "point" strikes to include the entire industry or even a number of industries. The effect of this was to place a heavy burden on the national unions and LO and inevitably to draw them into the dispute. SAF has constantly pressed for centralized negotiations in order to maintain a solid front and to avoid competition; the sympathetic lockout was an effective instrument for achieving that goal. ${ }^{61}$

The law is only one element contributing to centralization. Paragraph 32, by limiting collective bargaining to wages and other economic terms, made possible and encouraged bargaining by industry on a national level. Any local or regional variations in these terms that might be required could be prescribed in a national industry agreement. There was little need for supplementary local agreements on substantial issues.

Comprehensiveness of unionization in Sweden, combined with LO's wage policies, has also contributed to centralization. With more than ninety percent of workers covered by collective bargaining, large increases negotiated by one national union in one industry would be at the expense of members of other unions in other industries, and competition between unions for increases would generate a spiral of wage inflation. In the past the wage increases negotiated by unions had a visible impact on the national economy and the ability of Swedish industry to compete in world markets. During the post-war years LO came to recognize the need for a unified wage policy that would help provide economic stability and full employment. ${ }^{62}$ Recommendations by LO that its member national unions exercise wage restraints proved ineffective. This resulted in resort to central negotiations between the union and employer confederations that have now evolved to the stage where national wage negotiations are tied to governmental changes in social benefits and revisions in the tax system. ${ }^{63}$ Central negotiations have also been supported by LO to enable it to carry out its basic policy of seeking through collective bargaining to serve the social purpose of lifting the wages of employees in low wage industries, thereby reducing

6o R. FAHLbeck, Praktisk ARbetsRätt 126 (1981); C. HallendorfF, supra note 36, at 79-83, 157-61; F. SCHMIDT, supra note 8, at 162 .

61 A. Hadenius, Facklig Organisationsutveckiing 19-27 (1976).

${ }^{62}$ Id. at 68-96.

es LO, LO 80-RAPPORTEN: RAPPORT TILL LO-KONGRESSEN 1981, at 27 (1981); Jacobson, Vad hände under 1980ars konflikt?, in STORKONFLIKTEN 1980, at 30 (1981). 
disparities in earnings. ${ }^{64}$ This can be accomplished only through national interindustry bargaining. ${ }^{\mathrm{BS}}$

It should be noted that none of these conditions that led to centralization in Sweden has existed in the United States. Until relatively recently the sympathetic lockout was illegal $^{68}$ and even now cannot be used to compel central union control. ${ }^{67}$ There has never been a national employers federation equivalent to SAF in the United States. As has been pointed out, the national employers organizations have sought to combat or fragment collective bargaining and have actively supported legislation to prohibit industry-wide bargaining. ${ }^{68}$ There are employers associations in particular industries such as steel, rubber, coal-mining, construction, and various branches of transportation, but most of them are loosely organized, and they have no links with each other. ${ }^{69}$

Because only thirty percent of employees are covered by collective agreements, unions can gain by negotiating increases at the expense of the seventy percent not covered by collective agreements. Unions compete with one another, each getting the most possible for its members.

of A. HADENIUS, supra note 61, at 105-22.

os Central negotiations show some signs of fragmenting. In 1983 LO announced that it would not have centralized negotiations but would bargain by sectors. 110 EUR. INDUS. REL. REV. 3 (1983). The Metal Workers, the largest LO union, did negotiate a separate agreement for the metal industry. 112 EUR. INDUS. REL. REv. 8 (1983). The other LO unions, however, made a central agreement to end a twelve-hour strike that threatened a mass shutdown. The agreement followed the general pattern set by the Metal Workers. 111 EuR. INDUS. REL. REv. 2 (1983). In December LO said that it would not coordinate bargaining in the 1984 negotiations, 119 EUR. INDUS. REL. REv. 5 (1983), and the Metal Workers again negotiated separately in 1984, 121 EUR. INDUS. REL. REV. 5 (1983). Whether decentralized bargaining without substantial coordination by LO will prove feasible for a substantial period, however, is far from certain.

${ }^{68}$ See NLRB v. Brown, 380 U.S. 278, 283 (1965); NLRB v. Truck Drivers Local 449 (Buffalo Linen), 353 U.S. 87, 97 (1957); see also Meltzer, Lockouts Under the LMRA: New Shadows on an Old Terrain, 28 U. CHI. L. Rev. 614 (1961).

87 This would be considered a violation of the employees' right "to bargain through representatives of their own choosing," National Labor Relations Act, \& 7, 29 U.S.C. \& 157 (1982). The employer cannot use any economic pressure to interfere with the employees' free choice of bargaining representatives. See Detroit Newspaper Publishers Ass'n v. NLRB, 372 F.2d 569, 571 (6th Cir. 1967) (stating that unstruck employers may not use a lockout to coerce unions into bargaining trough a multi-employer bargaining unit).

es See Iserman, The Labor Monopoly Problem: Gwinn-Fischer Bill Would Effect Reforms, 38 A.B.A. J. 743 (1952). It should be emphasized that multi-employer bargaining has been held not to violate the antitrust laws so long as it is limited to required subjects of bargaining and is not aimed at injuring competitors who are not members of the employers' association. See United Mine Workers v. Pennington, 381 U.S. 657 (1965).

"9 Inquiry into Multiemployer Association Bargaining and Its Impact on the Collective-Bargaining Process: Hearings Before the General Subcomm. on Labor of the House Comm. on Educ. and Labor, 88th Cong., 2d Sess. 11 (1964) (statement of James A. Suffridge, President of the Retail Clerks Int'l Ass'n, AFL-CIO). 
Each union considers itself autonomous, and there is little incentive or pressure to develop a common wage policy. Wage increases, negotiated by unions separately, do not have the same obvious impact on the national economy here as in Sweden, and, even if they did, unions could not play the same role as their Swedish counterparts in shaping national economic policy.

Apart from the small size of bargaining units and the incomplete coverage of collective agreements, the most crucial factor explaining the decentralization of the American system is, in my view, the breadth of subjects regulated by collective bargaining. Because collective agreements in the United States reach subjects that relate so directly to working conditions, the production processes, the kind of work performed, and the employees' rights at the workplace, negotiations on many of these matters must be decentralized. More important, the dayto-day representation of employees when enforcing these provisions and resolving the multitude of problems they present requires constant dealing with the employer. This can be done effectively only at the workplace and requires, in turn, resources and authority at the local level. The result is that the local union is a substantial organization with considerable autonomy and important decision-making functions. Because it deals with those problems of most immediate concern to the employees and is constantly visible to the employees, the employees tend to identify the local union as the relevant union and develop a strong sense of loyalty to it. By the same token, local union officers and committee members see their functions as important and see themselves as representative of the employees in the plant. All of this builds a sense of local independence and resistance to centralization.

This sketch somewhat overstates the difference between the two systems. Central negotiations in Sweden are supplemented by national industry agreements that allocate the "pot" reserved from general increases to provide differential increases that will correct disparities and implement the solidarity wage policy. ${ }^{70}$ At the local level piece rates are negotiated, and the increases fixed at the central or industry level are often negotiated upward, even though this runs counter to the principle of central negotiation and the declared policies of the central organizations. ${ }^{71}$ On the other hand, in the United States some centrally negotiated agreements, such as those in trucking, leave little room for local

70 A. Victorin, LÖNENORMERING Genom Kollektivavtal (1973).

71 S. Edlund, TVisteförhandlingar Pa arbetsmarknaden 82 (1967); T. JoHNSTON, supra note 15, at 258-59, 284-85; MEDBESTÄMMANDE?: FACKLIGA ERFARENHETER FRAN MBLS TVA FÖRSTA AR, RAPPORT TILL. TCO'S 1979 KONGRESS 85-86. 
agreements, and in some unions local grievance procedures are subject to substantial central control.

This description of the difference in centralization of the two systems has not taken into account the changes contemplated by the Swedish Codetermination Act of 1976. This statute recognizes that worker participation in decisions at the workplace or enterprise level requires a substantial measure of decentralization. Section 14 provides that the right to negotiate concerning changes in the activities of the enterprise and changes in the work or employment conditions of an employee belong in the first instance to the local union organization or plant "club." Only if agreement is not reached at that level is negotiation to be taken up by the central organization. Similarly, under section 36, the power to exercise the right of priority of interpretation, ${ }^{72}$ and, under section 38, the authority to negotiate on the use of subcontractors belong in the first instance to the local organization. ${ }^{73}$ Also, under section 20, the employer has a duty to the local organization to provide information concerning the activities of the enterprise. ${ }^{74}$

72 The principle of "priority of interpretation" is a Swedish invention and is expressed in $\S 33$ of the MBL in the following terms: "Where a collective agreement contains provisions about a right of joint regulation . . . and . . . a dispute arises over application of [a section 32] provision . . . , the employee party's view [of the interpretation of the agreement] shall apply until that dispute has been finally tried." This reverses the practice in the United States, where the employer acts and the union grieves, with the employer's action continuing until the dispute is settled.

The principle as applied to the employees' duty to obey orders is stated in $\S 34$, which states, "Where, between an employer and an organisation of employees bound by the same collective agreement, a dispute arises over a member's duty, under an agreement, to perform work, the organisation's view [of the interpretation of the agreement] shall apply until that dispute has been finally tried." This reverses the commonly accepted principle that an employee must obey orders not dangerous to health and safety and grieve the employer's violation.

The principle is not applied to disputes on pay or other remuneration. Under $\S$ 35 , the employer's obligation is to call for negotiations, and, if the dispute is not settled, the employer must bring an action in court. If the employer fails to do this, it must pay the disputed amounts.

The sections are not applicable where there are "urgent reasons" against such application or the union's views are unreasonable. MBL \&33.

${ }_{73}$ Section 38, which restricts the employer's right to subcontract, provides, "Before an employer decides to allow anybody to perform certain work on his behalf or in his business without that person thereby being employed by him, he shall, on his own initiative, negotiate with any organisation of employees in relation to which he is bound by collective agreement for such work." Such prior negotiation is not required when the work is "of short duration and of a temporary nature as requires special skill" or if there are "extraordinary reasons against postponing the decision."

Under $\S 39$, the union has a right to veto the subcontracting when the union declares that it "may be taken to involve disregard of the law or of a collective agreement for the work" or is "in conflict with what is generally approved of by the parties concerned."

${ }^{76}$ The duty to provide information imposed by $\S 20$ is extremely broad, requiring the employer to keep the union "continuously informed about how his activity is devel- 
The commission report proposing the statute ${ }^{78}$ and all of the discussion leading up to the statute's passage emphasized that primary authority and responsibility for codetermination was to be placed at the local level. Both the unions and the employers seem to agree, at least in principle, that the functions of codetermination contemplated by the statute must be performed by the local organization dealing directly with the individual employer. ${ }^{76}$ Various codetermination agreements have been negotiated centrally, but these are all procedural agreements outlining the procedures to be followed at the local level in discussing and resolving various codetermination issues. The substantive results are left to local negotiations. ${ }^{77}$

The statute contemplates, in effect, that Swedish unions take a long step in the direction of American unions. Collective agreements concerning wages and other economic terms will presumably continue to be negotiated centrally, but the wide range of management decisions concerning the workplace and the enterprise encompassed by the statute will be negotiated locally. This will require strong workplace organiza-

oping in respect of production and economically and about guide lines for personnel policy" and to afford the union "an opportunity to examine books, accounts, and other documents which concern his activity."

${ }_{78}$ Demokrati pa arbetsplatsen, SOU 1975:1.

${ }^{76}$ See, e.g., SOLIDARISK MEDBESTÄMMANDE, RAPPORT TILL LO- KoNGRESSEN 13, 44, 92, 109 (1976); SAF Circular Letter No. 5 (1977). In their proposals for a central joint regulation agreement, LO/PTK stated in $\S 1$, "Joint regulation will be exercised by the local union organisations through negotiations and/or local joint regulation and cooperation forms according to this agreement." The SAF proposal was more emphatic, stating in its introduction, "It is, therefore, very important that it is the employees in the enterprise who exercise the joint regulation."

7 These include joint regulation agreements for the state sector, state-owned enterprises, local and county governments, banks, and cooperatives. The protocol to the Joint Regulation Agreement (MBA) for the state sector declared, "[T]he parties are agreed that the center point in codetermination shall be at the local level." It provides in $\S 14$ that "disputes shall primarily be negotiated locally between such authority . . . and the labor organization most immediately affected by the dispute." The local and county MBA provides in $\S 2$, "Codetermination ought therefore lie as near the employee as possible," and the bank MBA provides that the employer's obligation to negotiate and provide information under MBL may be fulfilled through the workplace representative or the local club. All of these joint regulation agreements provide for local codetermination agreements.

It is claimed that in the state sector decentralization seems not to have occurred because officials have failed to delegate authority so that there can be codetermination at the local level. M. Beronius, MedBestämmandeavtal PA Undantag? 106-07 (1981). The same author says that few local codetermination agreements have been made. See id. at 153 . Another report says that there are 140 local codetermination agreements in the state sector, although many are of limited scope. See LAG \& AvTAL, May 27, 1981.

LO and TCO opposed the making of local joint regulation agreements in the SAF sector until a central agreement was reached. This has slowed the progress at the local level. L. Lennerlof \& P. Hellberg, Medbestämmande enligt lag, VAd blev DET? SAMMANFATTANDE SluTRAPPORT 70 (1979). 
tions, for they will be performing functions similar to, but even more extensive and burdensome than, those of American local unions because of the breadth of codetermination subjects. More important, they must be given the power to make decisions because the national unions will not be able to oversee most of the decisions that affect workers.

If American experience is any guide, creating a local level of decision-making may significantly change the centralized character of Swedish unions. Under codetermination, the matters of most immediate importance to the employees will be negotiated at the local level by local representatives. Union members in Sweden will increasingly come to look upon the local organization that deals with their day-to-day needs as their union and see the national union as a remote entity that every year or two negotiates the leftovers from central negotiations. To be sure, the local organization will be a part of the national union and legally subject to its control. But the local organization with its increased functions, increased importance, and the increased loyalty of its members may assert and exercise a substantial degree of independence from the national union.

This probably overstates the decentralization that will occur; at least in the near future, for unions currently have no organization at most workplaces. The base level of organization is the district (avdelnin), and one of the consequences of past centralization is that now each of these often covers large areas and hundreds of workplaces. ${ }^{78}$ In larger establishments, clubs or sections may be organized. These may be quite active and effective organizations, although their existence is not recognized in many union statutes, and they have few, if any, financial resources. ${ }^{79}$ As a general rule no club is formed unless there are at least ten members of the particular union. This means that for both blue-collar and salaried employees to have clubs there must be more than twenty employees. Membership figures for SAF show that eighty-three percent of its members have fewer than twenty-five employees. ${ }^{80}$ Where no club exists, a contract representative may be desig-

${ }^{78}$ A. HADENiUS, supra note 61, at 161-67. Half the LO members are in districts of more than 4,000 members, and a third are in districts of 5,000 members. "For them, clubs or sections are a necessity if an ordinary member is to be able to take part in meetings." LO, LO 80-RAPPORTEN: RAPPORT TILL LO-KONGRESSEN 1981, at 112 (1981).

79 One exception is Metallindustriarbetareföbundt. For information on the weakness and absence of clubs, see Kallström, Lokala Kollektivavtal 22 (1979).

80 SVENSKA ARBETSGIVAREFÖRENINGENS VERKSAMHET 3 (1980). The total membership is 37,069 . Of these, 19,141 had fewer than five employees, 5,587 had between six and ten employees, and 5,994 had between 11 and 25 employees. These employers had $14 \%$ of the employees within SAF. It should be pointed out that many small employers are not members of SAF. 
nated from among the employees, but the nearest thing to a local organization is the district, which is a part of the present centralized structure. Any effective decentralization will have to come from strengthening clubs in relatively large establishments.

\section{Measures of Participation}

The similarities and contrasts outlined in the preceding Parts provide a background for comparing more directly the extent of employee participation in the American and Swedish systems at the present time. To measure participation, three questions must be asked: (1) In what decisions concerning their work and the activities of the enterprise do employees have a voice? That is, what is the scope of subjects for participation? (2) How are employees' voices heard in the decision-making process? More pointedly, how effective is their voice in influencing the decisions of management? (3) Because participation is almost entirely through representatives, how much voice do employees have in determining what their representatives do on their behalf?

\section{A. The Scope of Participation}

The National Labor Relations Act requires employers to negotiate with the majority union on "wages, hours and other terms and conditions of employment." These words are interpreted to reach beyond economic terms to include practically all matters directly relating to the employees' work: $:^{32}$ scheduling of work ${ }^{83}$ description of job duties and job classifications, ${ }^{84}$ assignment or transfer of employees to particular jobs, ${ }^{85}$ promotions, ${ }^{86}$ dismissals, ${ }^{87}$ job training, ${ }^{88}$ safety conditions, ${ }^{89}$ (1982).

${ }^{82}$ National Labor Relations Act, $\S 8(a)(5), 8(d), 29$ U.S.C. $\S 158(a)(5), 158(d)$

82 See generally R. GoRman, Basic Text on Labor Law: Unionization and Collective Bargaining 496-531 (1976).

${ }^{83}$ See Local 189, Amalgamated Meat Cutters v. Jewel Tea Co., 381 U.S. 676, 691 (1965); Fibreboard Paper Prods. Corp. v. NLRB, 379 U.S. 203, 222 (1964) (Stewart, J., concurring).

84 See Crown Goach Corp., 155 N.L.R.B. 625 (1965) (supervisors' and foremen's duties); Beacon Piece Dyeing and Finishing Co., 121 N.L.R.B. 953 (1958) (workloads).

80 See NLRB v. A-1 King Size Sandwiches, Inc., 732 F.2d 872, 877 (11th Cir. 1984); NLRB v. Laney \& Duke Storage Warehouse Co., 369 F.2d 859, 869 (5th Gir. 1966); Southwestern Bell Tel. Co., 247 N.L.R.B. 171, 173 (1980).

${ }_{\text {s6 }}$ See Southwestern Bell Tel. Co., 247 N.L.R.B. 171, 173 (1980).

87 See National Licorice Co. v. NLRB, 309 U.S. 350, 360 (1940).

${ }^{88}$ See Flambeau Plastics Corp. v. NLRB, 401 F.2d 128, 134 (7th Cir. 1968), cert. denied, 393 U.S. 1019 (1969); Genser v. IBEW Local 134, 522 F. Supp. 1153, 1161 (N.D. Ill. 1981).

89 See Fibreboard Paper Prods. Corp. v. NLRB, 379 U.S. 203, 222 (1964) (Stew- 
contracting out of work, ${ }^{80}$ and even the kind of meals served in the cafeteria. $^{\text {91 }}$

The duty to negotiate in the United States, however, does not reach what the Supreme Court has described as "managerial decisions which lie at the core of entrepreneurial control."92 Thus an employer is not required to negotiate a decision to close down a part of the enterprise, add a new facility, sell the business or merge with another, introduce new technology, or change products. ${ }^{93}$ Although such decisions have a direct and vital effect on the number of jobs or the work to be performed, the employer has no duty to negotiate because the decisions involve "the scope and directions of the enterprise." Plainly, decisions about matters that have less direct impact on employees, such as investment or withdrawal of capital, amount and form of financing, character of advertising, or extent of sales promotion, are beyond the employer's duty to bargain. ${ }^{95}$

In Sweden the scope of the legal duty to negotiate was undefined and of no practical concern before 1976. The Act on Freedom of Association and Right of Negotiation of $1936^{96}$ established in section 4 the right to negotiate "respecting the adjustment of conditions of employment and respecting the relations between employers and employees in general." Wh Whether there was any limit on the subjects concerning which the union could call for negotiations under this section was uncertain..$^{88}$ The unions' acceptance of the narrow scope of collective agreements allowed by paragraph 32 made the issue irrelevant. In 1976

art, J., concurring); NLRB v. Gulf Power Co., 384 F.2d 822, 825 (5th Cir. 1967).

${ }_{90}$ See Fibreboard Paper Prods. Corp. v. NLRB, 379 U.S. 203 (1964).

21 See Ford Motor Co. v. NLRB, 441 U.S. 488, 503 (1979).

92 Fibreboard Paper Prods. Corp. v. NLRB, 379 U.S. 203, 223 (1964) (Stewart, J., concurring).

os First Nat'l Maintenance Corp. v. NLRB, 452 U.S. 666, 676-77, 686 (1981); Fibreboard Paper Prods. Corp. v. NLRB, 379 U.S. 203, 223 (1964) (Stewart, J., concurring).

- First Nat'l Maintenance Corp. v. NLRB, 452 U.S. 666, 676-77 (1981). The employer is required to bargain about the effects of such decisions. Id. at 681 . This includes bargaining about, for example, which employees will be dismissed and which will be transferred, what retraining shall be provided, and what, if any, severance pay shall be given. See, e.g., NLRB v. Royal Plating \& Polishing Co., 350 F.2d 191, 196 (3d Cir. 1965). But the employer is not required to notify the union in advance that such a decision is being considered or to discuss with the union whether it should be made. First Nat'l Maintenance, 452 U.S. at 676-77.

9s Fibreboard Paper Prods. Corp. v. NLRB, 379 U.S. 203, 223 (1964) (Stewart, J., concurring).

98 Lag om Förennngsöch förhandlingsrätt den 11 September 1936 (Act Respecting the Right of Association and the Right of Collective Bargaining), translated in $\mathrm{F}$. ScHmid, supra note 4 at 251-58 (1962).

97 $I d$. at 252.

98 Demokrati pa arbetsplatsen, SOU 1975:1, at 272-73, 281. 
the Codetermination Act, in section 10, redefined the union's right of negotiation to include "any matter relating to the relationship between the employer and any member of the organization who is or has been employed by that employer." tended to limit the scope of negotiations, and, at least for business enterprises in the private sector, the subjects on which the union can require the employer to negotiate are in practical terms unlimited. ${ }^{\mathbf{1 0 0}}$

Section 11 of the statute imposes on the employer a so-called "primary duty" to negotiate-a duty to initiate negotiations before taking action. ${ }^{101}$ The primary duty can be contrasted with the "general duty" to respond to the union's request for negotiations. The primary duty is narrower than the general duty, but it still reaches far beyond any duty imposed by American law. The Swedish employer must initiate negoti-

92 In full, $\$ 10$ provides,

An organisation of employees shall have a right to negotiate with an employer on any matter relating to the relationship between the employer and any member of the organisation who is or has been employed by that employer. An employer shall have a corresponding right to negotiate with an organisation of employees.

A right of negotiation under the first part of this section shall also be enjoyed by the organisation of employees in relation to any organisation to which the employer belongs, and by the employer's organisation in relation to the organisation of employees.

MBL \& 10, translated in F. ScHMIDT, supra note 4, at 235.

${ }^{100}$ The subject area "ought to be made so wide that no questions are excluded over which it is important for the workers to obtain influence." Demokrat pa arbetsplatsen, SOU 1975:1, at 282. "In principle, the subject area should include every question which concerns the relationship between employer and employee with respect to the work and the activity within which the work is carried on. The question may also relate to the enterprise's production, business management, work management or other matters." Prop. 1975/76: 105, bil. 1, at 209. See also R. FAHLBECK, PrakTiSK ARBETSRÄTT 57-58 (1981).

101 Section 11 provides,

Before an employer decides on important alteration to his activity, he shall, on his own initiative, negotiate with an organisation of employees in relation to which he is bound by collective agreement. The same shall be observed before an employer decides on important alteration of work or employment conditions for employees who belong to the organisation.

If urgent reasons so necessitate, the employer may make and implement a decision before he has fulfilled his duty to negotiate under the first part of this section.

MBL $\S 11$, translated in F. SCHMIDT, supra note 4, at 235-36. The "general duty" is defined in $\S 12$ as follows:

Should an organisation of employees which is referred to in $\S 11$ so request, an employer shall also, in a case other than those mentioned therein, negotiate with that organisation before he makes or implements a decision which concerns a member of the organisation. If special reasons so necessitate, however, the employer may make and implement the decision before he has fulfilled his duty to negotiate.

MBL § 12, translated in F. ScHMIDT, supra note 4, at 236. 
ations before making an "important alteration to his activity" or any important alteration of working or employment conditions for employees."102 These words were intended to reach those decisions that "one would typically expect a union to wish to have an opportunity to negotiate about,"103 including decisions concerning the opening of new plants, closing of existing plants, reducing operations, changing the location of the enterprise or parts of the firm, and other major investment decisions. ${ }^{104}$

The Labor Court has given added content to the words, holding that there is a duty to negotiate before deciding to introduce a new type of machinery, ${ }^{105}$ move control of a plant from one subsidiary to another, ${ }^{108}$ sell the company, ${ }^{107}$ or hire a new managing director, ${ }^{108}$ production chief, ${ }^{109}$ administrative head, or foreman. ${ }^{110}$ In the United States these would be considered decisions concerning "the scope and direction of the enterprise"111 or reaching "the core of entrepreneurial control,"112 decisions in which the employees would be entitled to no voice. They could be decided unilaterally by the employer without any notice to the union, the union could not insist on discussing these subjects, and employees would have no right to strike or take other economic action in protest against the employer's decision or the employer's refusal to discuss his decision. ${ }^{118}$

This comparison of the legal duty to negotiate does not give a full picture of either the potential or actual scope of participation. In the United States the union and employer are free to negotiate on almost any subject they mutually agree is negotiable, ${ }^{114}$ as long as it does not encroach on the rights of third parties or violate the law. Thus the potential scope of participation is substantially as broad as in Sweden. The employer, however, can refuse to discuss so-called permissive or nonmandatory subjects, and the union cannot strike to compel the employer either to discuss such subjects or to agree about them. ${ }^{115}$ In prac-

102 MBL § 11, translated in F. Schmid, supra note 4, at 235.

103 Prop. 1975/76:105, bil. 1, at 353.

104 Id. at 354; $\mathrm{AD}$ 1978:29, 51, 110 (government report).

108 See AD 1980:63 (labor court report).

106 See AD 1979:1 (labor court report).

107 See AD 1980:49, 81 (labor court report).

108 See AD 1980:72; AD 1981:8 (labor court report).

109 See AD 1979:118 (labor court report).

110 See AD 1980:163; AD 1981:13 (labor court report).

111 First Nat'l Maintenance Corp. v. NLRB, 452 U.S. 666, 677 (1981).

112 Fibreboard Paper Prods. Corp. v. NLRB, 379 U.S. 203, 223 (1964) (Stewart, J., concurring).

${ }_{113}$ NLRB v. Wooster Div. of Borg-Warner Corp., 356 U.S. 342, 349 (1958).

114 Id.

115 Id. 
tice most employers will not negotiate on subjects beyond those that are legally required.

The scope of participation in the United States, in fact, usually does not encompass all of the required subjects of bargaining, for the employer can negotiate for a provision in the collective agreement that certain matters be within his unilateral control during the contract term. ${ }^{116}$ This "management prerogatives clause" may, for example, give the employer the right to change work schedules, determine job duties, transfer employees, or contract out work-all without notice or discussion with the unions. Not only can the employer negotiate for such a clause, but he can refuse to sign an agreement or lock out his employees until the union agrees. ${ }^{117}$

Swedish employers are similarly permitted to use their bargaining power to reduce the required scope of negotiations. Under section 4 of the Codetermination Act, the Employer's Confederation or one of its member associations could demand a provision in a collective agreement that would shrink the duty to negotiate and reinstitute, in whole or in part, the employer's right to direct and assign the work. This demand could be supported by a lockout.

The practical situation in the two countries, however, is quite different. The Employer's Confederation would not seek, and the unions could not accept, any agreement that substantially reduced the rights of codetermination established by the statute. In the United States, by way of contrast, almost every agreement has a management prerogatives clause that gives the employer unilateral control over negotiable subjects. Although management's reserved rights during the contract term are rarely as broad as the earlier paragraph 32 clauses in Swedish agreements, the scope of participation is substantially narrowed to cover an area smaller than the legally required subjects of bargaining.

An essential element of the right to participation in the decisions of the enterprise is the right to receive information relevant to those decisions. The scope of this right is much broader in Sweden than in the United States. First, the Swedish statute requires the employer to take the initiative in regularly providing the union with relevant information. ${ }^{118}$ The American employer has no such affirmative obligation but is required to produce information only when the union specifically requests it. ${ }^{118}$

118 NLRB v. American Nat'l Ins. Co., 343 U.S. 395, 409-10 (1952).

${ }^{117}$ See id.

118 MBL $\S 19$, translated in F. ScHMIDT, supra note 4, at 237.

119 See NLRB v. Truitt Mfg. Co., 351 U.S. 149 (1956); Kroger Co. v. NLRB, 399 F.2d 455 (6th Cir. 1968); NLRB v. Robert S. Abbott Publishing Co., 331 F.2d 209 
Second, in the United States the right of unions to information is limited to that relevant for bargaining. ${ }^{120}$ Because the subjects on which bargaining is required are limited, the scope of information to which the union is entitled is thereby circumscribed. In Sweden the unlimited scope of bargaining precludes any such circumscription.

Third, unions in the United States are not entitled even to all information that they reasonably believe necessary for bargaining. They are entitled to a wider range of personnel information, such as the wage rates and earnings of each employee; the number of employees of each employer; the number of employees in each classification; and data regarding merit increases, promotions, hirings, layoffs and the costs of holidays, vacations, pensions, and other benefits. ${ }^{121}$ However, unions are almost never entitled to information concerning the general business activities of the enterprise, its productivity, profitability, ${ }^{122}$ competitive position, financial plans, or market prospects, even though this information might be crucial to the union in developing its bargaining policies on wages and other terms or conditions of employment. ${ }^{123}$ In Sweden the union is entitled to all relevant information, including the salaries of executives and other employees not covered by the collective agreement, unit costs of production, the number of units produced, the sales price, and the profit margin. The union is entitled to examine the books and accounts to verify this information. In addition, the employer must inform the union of plans for expansion, contraction, the introduction of new products, or other changes in the activities of the enterprise. The right to participate in all decisions of the enterprise that affect the employees' welfare and interests is matched by the right to have full information concerning the activities and plans of the enterprise. ${ }^{124}$

How can we explain these marked differences between the two

(7th Cir. 1964).

${ }^{120}$ Bartosic \& Hartley, The Employer's Duty to Supply Information to the Union-A Study of the Interplay of Administrative and Judicial Rationalization, 58 CoRnell L. Rev. 23 (1972).

${ }^{121}$ See R. Gorman, Basic TeXt on Labor Law 411 (1976) (presumption under the NLRA that a wide variety of wage and fringe benefit information is relevant and must be disclosed by the employer).

122 However, if the employer, during negotiations, claims that it cannot meet the union's demands because of its financial condition, it may be required to provide the financial information to show that this is true. See NLRB v. Truitt Mfg. Co., 351 U.S. 149, 153-54 (1956).

${ }^{123}$ Shedlin, Regulation of Disclosure of Economic and Financial Data and the Impact on the American System of Labor-Management Relations, 41 OHIO ST. L.J. 441 (1980).

${ }_{124}$ F. Schmid, supra note 4, at 115-19; Prop. 1975/76:105, at 231-39 (government report). 
countries in the scope of subjects about which the employer is required to negotiate and in the scope of information that the employer is required to provide? In my view two interrelated factors have contributed to the difference. First, in the United States the duty to bargain and the right to strike have been viewed as opposite sides of the same coin. If a matter is a mandatory subject of bargaining, then the union can legally strike concerning that matter; if the matter is not a mandatory subject of bargaining, then the union cannot legally strike. ${ }^{125} \mathrm{~A}$ determination that the employer is not required to bargain on a particular subject expresses a judgment that the employer should be able to make decisions on that subject free from economic pressure by the union. The premise is that certain decisions of management should be legally shielded from union economic action-a premise historically accepted by American courts in limiting the objectives for which a union could legally strike. ${ }^{126}$ Sweden never developed any such legal limits on the objects for which a union could strike. There was little need, for the Employers Confederation, achieved by agreement in the December Compromise of 1906, imposed limits much narrower than those since imposed by American law.

The second and more fundamental reason for the difference in the scope of participation in the two countries is that the National Labor Relations Act and Swedish Codetermination Act are built on quite different premises. The National Labor Relations Act conceives of collective bargaining and the relation of the union and the employer as predominately one of confrontation. According to the Supreme Court in First National Maintenance Corp. v. NLRB, ${ }^{12 z}$ "Congress had no expectation that the elected union representative would become an equal partner in the running of the business enterprise in which the union's members are employed."

To maintain the adversarial structure and to keep the opposing parties in balance, the law must shield the employer's "core of entrepreneurial control"128 from participation by the union. In holding that an employer need not negotiate before deciding to close down a

125 See NLRB v. Wooster Div. of Borg-Warner Corp., 356 U.S. 342, 349 (1958).

${ }^{126}$ Haverhill Strand Theatre, Inc. v. Gillen, 229 Mass. 413, 118 N.E. 671 (1918) (requiring hiring of more musicians than desired); DeMinico v. Craig, 207 Mass. 593, 94 N.E. 317 (1911) (requiring discharge of a foreman); Reynolds v. Davis, 198 Mass. 294, 84 N.E. 457 (1908) (requiring employer to follow union rules); Opera on Tour, Inc. v. Weber, 285 N.Y. 348,34 N.E.2d 349, cert. denied, 314 U.S. 615 (1941) (preventing use of technological devices); Welinsky v. Hillman, 185 N.Y.S. 257 (Sup. Ct. 1920) (preventing employer from closing a department).

127452 U.S. 666, 676 (1981).

128 Fibreboard Paper Prods. Corp. v. NLRB, 379 U.S. 203, 223 (1964) (Stewart, J., concurring). 
part of his operations, the Court said that the "employer's need for unencumbered decisionmaking" must be weighed against "the benefit, for labor-management relations and the collective bargaining process,"129 and concluded, "[T]he harm likely to be done to an employer's need to operate freely in deciding to shut down part of its business purely for economic reasons outweighs the incremental benefits that might be gained through the union's participation in making the decision."130

The Supreme Court views employees and the union not as partners, but as antagonists of the employer with separate and conflicting interests. Indeed, in $N L R B$ v. Yeshiva University, ${ }^{131}$ the. Court declared that faculty members who had a voice in university decisions should be excluded from collective bargaining because the employer was entitled to the "undivided loyalty"132 of those who participated in management decisions. Collective bargaining was only for adversaries of management; it was not a process for participation in management.

The Swedish Codetermination Act, in contrast, stands on the premise that management and the employees are partners in the enterprise and that the employees are entitled to participate in decision-making. The employees, as full partners, are entitled to full knowledge of all aspects of the business and to a voice in all of its activities. ${ }^{133}$ The statutory repudiation of paragraph 32 left no shielded area of management prerogatives, and the decision-making process is to be one not of confrontation, but of codetermination. This view of the role of employees, speaking through the union, leads to the nearly unlimited scope of participation and information in Swedish law.

The premise of codetermination by employees and employers was laid down in the first legislation on worker participation in the early 1970's - the Act on Board Representation for Employees of Joint Stock Companies and Cooperative Associations of 1972, ${ }^{134}$ - which gave employees the right to elect two members to sit on the board. Explicit recognition was thereby given to the principle that employees were to be partners in the enterprise, entitled to a voice in all decisions of the enterprise. As stated by LO in proposing such legislation, "Representation on the Board would serve to indicate that workers are part of the firm and that they have a right to give their views on its activities

\footnotetext{
129 First Nat'l Maintenance, 454 U.S. at 679.

130 Id. at 686.

131444 U.S. 672 (1980).

182 Id. at 682.

1ss See R. FAHLBECK, supra note 101, at 43-45.

13: The Act expired in June 1976 and has been replaced by the Act of the same name of 1976. See F. ScHMIDT, supra note 4, at 85.
} 
before any final decisions are taken."135 In disposing of the argument that board membership would create dual loyalties, LO declared, "It is quite incorrect to regard the workers' interests as being opposed to the firm's. In fact, the workers are part of the firm, so they cannot be at variance with it."136

In the United States there has not been even serious consideration of providing by law for employee representation on corporate boards. The rare examples of such representation ${ }^{\mathbf{1 3 7}}$ are overshadowed by the explicit declarations of leading union officers that it is inconsistent with the union's collective bargaining function. ${ }^{138}$ The dominant view of both unions and employers has been that they are adversaries and that collective bargaining is a process of confrontation. The premise of partnership and joint interest in the enterprise has been largely rejected, with the result that the scope of employee participation has not encompassed many management decisions in which the employees have a vital interest. The Swedish statute, by contrast, is built on the premise that employees are partners in the enterprise and are therefore entitled to a voice in all decisions that affect their interests.

196 LO, Industrial Democracy, Programme adopted by the 1971 LO CoNGRESS 107.

136 Id. Representation has provided employees with relatively little influence over decisions, but it has given them a better opportunity to observe and understand the operation of the enterprise and its problems. SIND 1975:4, UTREDNING FRAN STATENS INDUSTRIVERK, STYRELSE REPRESENTATION FÖR ANSTÄLIDA, ENFARENHETER FRAN FÖRSÖKSPERIODEN 257 (1975).

137 The most noted example is the election of the president of the auto workers to the board of Chrysler. Three special elements are worthy of note: (1) he was elected by the members of the board, not the union; (2) he is the only employee member on a large board; and (3) his election was motivated primarily by the need to get the support and cooperation of the union in obtaining large government loans to keep the company from bankruptcy. See N.Y. Times, May 14, 1980, at D1, col. 3.

There has been discussion of having a union officer on the corporate boards of Ford and General Motors as part of an agreement by the union to reduce wages and benefits, but these proposals have neither been pressed by the union nor accepted by the companies.

138 The president of the AFL-CIO (then secretary-treasurer) stated the union's opposition to workers becoming partners in these blunt terms: "[The American worker] is smart enough to know, in his bones, that salvation lies-not in the reshuffling of chairs in the board room or in the executive suite-but in the growing strength and bargaining power of his own autonomous organizations." Ellenberger, The Realities of Co-Determination, AFL-CIO AM. FeDERATIONIST, Oct. 1977, at 15 (statement of Lane Kirkland). This view was echoed by the president of the Machinists union, who declared, "We have no interest in replacing free enterprise with a more utopian system .... And we believe workers can receive a better share of the fruits of free enterprise at bargaining tables than in board rooms." Id. (statement of William W. Winpisinger). Within the last two years there has been some softening of this opposition, but there is still no general support for employee membership on corporate boards. 


\section{B. The Effectiveness of Participation}

To measure employee participation in the two countries, it is necessary to compare not only the scope of subjects in which employees have a voice, but also the effectiveness of their voice in influencing decisions on such subjects. To what extent are the decisions different than they would have been if there had been no participation?

To make this comparison, it is necessary to discuss separately those decisions concerning wages and other economic terms-the traditional subjects of collective agreements in Sweden-and those decisions concerning direction of the work and management of the enterprise-the area newly embraced by the Codetermination Act. Both the method and the character of participation in these two areas are quite different in the two countries. Economic and noneconomic subjects are handled quite separately in Sweden, whereas they are almost completely merged in the United States.

\section{Wages and Economic Terms}

In both Sweden and the United States, disputes over wages and other economic terms may be resolved by economic conflict. In principle the effectiveness of the employees' voice ultimately depends on the effectiveness of the strike and lockout.

In the United States the union's economic strength varies widely from industry to industry and from employer to employer. The Auto Workers union can completely close down General Motors, which then sees its potential customers buying Fords or Volkswagens. The Steelworkers union can close down the steel industry, which then is pressured by the automobile companies and other users of steel to settle. The Teamsters union can paralyze trucking, and all shippers become willing to accept an increase in freight rates. On the other hand, a strike called by a union of hotel workers may be observed by only half of the employees, and the hotel will remain open or the customers will go to another hotel. A strike by garment workers may only drive business to nonunion plants or to imports; a strike by textile workers can be suicidal because the strikers' jobs may be taken by strikebreakers. Thus the effectiveness of participation in unionized industries and enterprises ranges from a very high level to a level that borders on total ineffectiveness. One result of this difference in effectiveness is a great disparity in wages and other benefits within unionized as well as nonunionized industries. ${ }^{138}$

139 One union leader has described the result as a "two-tier labor force," with 
In Sweden the strike is a potentially powerful weapon in every industry since the unions can effectively close down any or all establishments. But the lockout is an equally powerful weapon to counteract the strike. More important, centralization of negotiations, centralized control of the strike and lockout, and the use of sympathetic economic action largely preclude open economic conflict. The national organizations refuse to sanction or support strikes or lockouts in specific enterprises, for they will almost inevitably spread by sympathetic action to the entire industry. A strike called in one industry will be countered by a lockout in related industries, which will in turn be countered by strikes in still other industries. The legality of and willingness to use sympathetic action means that a limited action can expand in ever widening circles until almost the entire private and public sectors are brought to a standstill.

This prospect of this happening is always present, and it occurred in 1980 when successive calls for sympathetic strikes and lockouts spread a dispute until the whole Swedish economy and most public services were closed down for a week. ${ }^{140}$ As this experience dramatically demonstrated, the strike and lockout are equally powerful, so as to be weapons of mutual destruction that neither party can afford to use. They contribute to a system of mutual deterrence that puts heavy pressure on both parties to resolve their problems by negotiation rather than by economic conflict. ${ }^{141}$ Those negotiations, as was suggested earlier, must be linked with governmental decisions on social benefits and taxes that can add to or subtract from the wages negotiated in the central agreement.

The effectiveness of the employees' voice in determining their wages and economic terms in Sweden is thus ultimately measured by the unions' ability to influence, in conjunction with central negotiations, the national economic policy. This depends less on the effectiveness of the strike than on the political and economic climate for making that policy.

In general terms it is impossible to compare the effectiveness of the employees' voice in determining wages and other economic terms in the two countries. What can be said is that in the United States effectiveness depends more on the union's ability to strike, whereas in Sweden

high-wage unions and low-wage unions. S. Chaiken, A Labor Viewpornt: ANOTHER OPINION 115-21 (1980).

140 See generally STORKONFLIKTEN 1980 (A. Broström ed. 1981).

141 There is always, in the background, the possibility of government intervention by legislation. During the 1971 strike by SACO and SR, legislation was passed to impose a continuation of the collective agreements, thereby subjecting the parties to the peace obligation and ending the strike. See F. Schmidt, supra note 4, at 196. 
effectiveness depends more on the union's political strength and the political and economic context. In Sweden the voices of all employees are relatively equal, with the voice of low-wage groups given priority. In the United States employees in strong unions have strong voices, employees in weak unions have weak voices, and seventy percent of the employees have no voice at all. The low-wage groups are among those who have a weak voice or who are entirely voiceless.

\section{Noneconomic Terms}

Comparing the effectiveness of participation in matters beyond wages and other economic terms in these two countries is much more complicated. Although many of the legal rules are remarkably similar, differences in the character of the collective agreement and the accepted method of dealing with these matters lead to quite different results. A brief analytical sketch of the collective bargaining process through which employees participate in in the United States will provide a basis for comparison.

To analyze the participation process in the United States, it is necessary to distinguish between the process before a collective agreement is made and the process after it is made. Prior to making a collective agreement, an employer cannot make any change in any mandatory subjects of bargaining without first bargaining with the majority union. ${ }^{142}$ The employer is responsible for initiating negotiations, and he must bargain in good faith to impasse-until it appears that further negotiation would be fruitless-before he can make the change.

This duty not to make unilateral changes without first bargaining to impasse parallels the primary duty to negotiate created by section 11 of the Swedish Codetermination Act. In both countries this duty makes the employees' voice more effective because it enables them to have their say before the decision is made. In both countries the union may legally strike to influence that decision. The rule in Sweden has a broader impact because, as pointed out earlier, it reaches many management decisions that are far beyond the scope of mandatory subjects in the United States. ${ }^{143}$

Negotiations leading up to the collective agreement in the United States customarily involve a wide range of subjects beyond wages and other economic terms and potentially include all mandatory subjects of bargaining. The purpose of the negotiations is to establish substantive

163 NLRB v. Katz, 369 U.S. 736, 743 (1962); NLRB v. Crompton-Highland Mills, Inc., 337 U.S. 217, 225 (1949).

${ }^{143}$ See supra text accompanying notes 80-115. 
rules to govern those matters during the contract term. The negotiations may, for example, prescribe detailed seniority rules governing the order of layoffs and rehires, establish standards to determine who shall be promoted to better jobs, state the circumstances under which employees may be transferred, regulate who shall perform overtime work, and fix the number of employees to be used on certain operations. All of these rules or standards are negotiated along with wages and other economic terms as a single package, and, if the parties are unable to agree on a package, the union may strike or the employer may lockout. ${ }^{144}$ The employees' voice on all of these noneconomic terms is heard in the same way and with the same effectiveness as their voice on wages.

After the collective agreement is made, the situation is significantly changed, for the employer is now legally bound by the substantive rules of the collective agreement. If economic conditions require a layoff, the employer need not discuss with the union who should be laid off, for the collective agreement controls. If he does not follow the seniority rules prescribed by the collective agreements, he is liable for breach of contract. The employer need not discuss with the union before he makes a promotion; but if the union believes that he has not properly applied the contractual standard, it can file a grievance and obtain an adjudication on that issue. ${ }^{146}$ If the collective agreement provides that five men are required to operate a machine, the employer cannot, either before or after negotiations, assign four men, at least without the consent of the union. The employer's primary obligation during the contract term is to act in accordance with the collective agreement; he has at most a limited obligation to discuss additions to or changes in the rules established by the agreement. ${ }^{146}$

It is important to emphasize that not all of the limitations on the

144 See Ford Motor Co. v. NLRB, 441 U.S. 488 (1979); Fibreboard Paper Prods. Corp. v. NLRB, 379 U.S. 203 (1964); NLRB v. Wooster Div. of Borg-Warner Corp., 356 U.S. 342 (1958); NLRB v. American Nat'l Ins. Co., 343 U.S. 395 (1952).

145 Whether an employer has violated the collective agreement is usually determined by an arbitrator, for over $90 \%$ of collective bargaining agreements provide that disputes as to interpretation and application of the agreement shall be submitted to arbitration. C. Summers, H. Wellington \& A. HYde, Labor LAw, Gases aNd MATERIALS 761 (1982). The arbitrator can determine what remedy is appropriate, but he cannot normally impose a penalty.

146 The scope of the employer's legal duty to bargain during the contract term is highly uncertain. There seems to be no duty to bargain over matters discussed and agreed upon during negotiation of the agreement but not included in the written agreement, Nelson \& Howard, The Duty to Bargain During the Term of an Existing Contract, 27 LAB. L.J. 573, 583 (1976), but there is a duty to bargain on matters neither discussed during negotiations nor embodied in the terms of the agreement, Jacobs $\mathrm{Mfg}$. Co., 94 N.L.R.B. 1214, 1219 (1951), affd sub nom. NLRB v. Jacobs Mfg. Co., 196 F.2d 680 (2d Cir. 1952). 
employer are necessarily found in the words of the agreement. There may be many silent or implied terms based on surrounding circumstances or the assumed understanding of the parties. One of the main sources of silent or implied terms is past practices. If in the past the employer has allowed employees five minutes working time to wash up before going home, a court or arbitrator may find that he is contractually bound to continue that practice even though no mention is made of it in the agreement. The job duties of a particular position may be defined by past practice without any contractual language, and whether an employer may contract out work may depend on whether he has contracted out such work in the past. ${ }^{147}$

On the other side the employer is generally free to act as long as he stays within the express and implied rules laid down by the agreement, and he can usually act without first negotiating with the union. Although the National Labor Relations Board has intermittently held that an employer must bargain before making any changes unless there is a waiver by the union, ${ }^{148}$ the dominant view of the collective agreement is that it settles all potentially negotiable matters and frees the employer of the duty to negotiate about them during the contract term. ${ }^{149}$ To the extent that the agreement does not expressly or impliedly limit his freedom to act, it gives him full freedom to act unilaterally. This is commonly articulated in the management prerogatives clause and is reinforced by so-called "waiver" or "zipper"150 clauses.

In the United States the collective agreement carries with it no statutory peace obligation as it does in Sweden, but most collective

147 See Mittenthal, Past Practice and the Administration of Collective Bargaining Agreements, 59 Mich. L. REv. 1017, 1030-40 (1961); Wallen, The Silent Contract vs. Express Provisions: The Arbitration of Local Working Conditions, 15 NAT'L ACAD. ARB. 117, 123-34 (1962).

${ }_{148}$ See, e.g., Western Mass. Elec. Co., 228 N.L.R.B. 607 (1977), enforced as modified sub nom. Western Mass. Elec. Co. v. NLRB, 573 F.2d 101 (1st Cir. 1978). But see McDonnell Douglas Corp., 224 N.L.R.B. 881, 895-96 (1976).

149 See generally Cox \& Dunlop, The Duty to Bargain Collectively During the Tern of an Existing Agreement, 63 HARv. L. REv. 1097 (1950); Mittenthal, The Role of Law in Arbitration, 21 NAT'L ACAD. ARB. $42-58$ (1968).

${ }_{100}$ These clauses, which may be worded in various ways, generally state that all terms and conditions of employment have been settled and agreed upon by the collective agreement and that the union waives any right to bargain during the term of the contract about terms not expressly included in the agreement. The legal effect of these clauses is uncertain because of contradictory decisions by the NLRB. See, e.g., PepsiCola Distrib. Co., 241 N.L.R.B. 869, 870 (1979) (presence of zipper clause did not preclude implying continued right to bonus), affd sub nom. NLRB v. Pepsi-Cola Distrib. Co., 646 F.2d 1173 (6th Gir. 1981), cert. denied, 102 S. Ct. 1993 (1982); Radioear Corp., 214 N.L.R.B. 362, 363-64 (1974) (presence of zipper clause did preclude implying continued right to bonus); Bancroft-Whitney Co., 214 N.L.R.B. 57, 5758 (1974) (presence of zipper clause did preclude implying right to bargain for wage dividend). 
agreements include a no-strike clause. If the employer takes unilateral action that does not violate the agreement, the union is barred by the no-strike clause from trying to influence that decision. The parties can, and sometimes do, limit the no-strike clause so that the union can strike on certain matters during the contract term. For example, collective agreements in the auto industry do not fix the speed of the assembly line, but contemplate that changes in the speed are to be negotiated, and if no agreement is reached, the union can strike. Such provisions, however, are exceptional.

The Board's decisions, to the extent that they impose a duty to bargain during the contract term, parallel sections 11 and 13 of the Codetermination Act in that they limit the employer's freedom to make changes in existing employment conditions. Again, the duty in the United States is much narrower because it extends only to mandatory subjects.

Many of the legal rules relating to the duty to bargain in Sweden so closely parallel those in the United States that if the structure of collective agreements and the scope of mandatory subjects were the same, the results would be substantially equivalent. There are, however, two basic structural differences between the two countries. First, in Sweden negotiation of wages and other economic terms is not merged with negotiations on other matters embraced by the Codetermination Act, and no single agreement is made encompassing all matters on which there is a duty to negotiate. Collective agreements on wages and other economic terms have substantially the same form and narrow scope now as they had prior to the passage of the Act. Other matters, previously reserved to management by paragraph 32 clauses but not required subjects for negotiation under the statute, are meant to be covered by separate codetermination agreements. The separation is symbolized by the fact that not until 1982, six years after the statute was enacted, was any central codetermination agreement negotiated with the Swedish Employers Confederation, which represents the major part of the private sector, although three central wage agreements had been negotiated in the meantime. ${ }^{151}$ Even then, the codetermination agreement was only a preliminary or partial agreement contemplating further negotiations. ${ }^{162}$

The second, and most critical structural difference is that codetermination agreements are conceived as procedural, not substan-

161 For the text of these wage agreements, see MBA-S (covering state sector employees), 1978; MBA-B (covering bank sector employees), 1979; MBA-KL (covering local and provincial sector employees), June, 1980.

162 Utvecklingsavtal SAF-LO/PTK, April 4, 1982. 
tive, agreements. The agreements thus far negotiated, including the ones for the public sectors and for the banks and cooperatives, have few if any substantive rules or standards governing the employer's decisions. Instead, the agreements provide organizational structures and procedures to be followed by the parties in negotiating the substantive matters within their scope at the plant or enterprise levels. Indeed, proposals going beyond procedure to substance were not even seriously considered in the negotiations leading up to these central agreements. ${ }^{153}$

The fact that these central joint regulation agreements are procedural rather than substantive is quite understandable. Unlike the more localized American agreements, they cover an extremely wide variety of situations. Designing substantive rules suitable for all those not covered would be impractical, if not impossible. Locally negotiated solutions are more appropriate. In addition the subjects covered include many matters with which collective agreements in the United States do not deal and which may not be suitable for regulation by substantive rules. For example, it would be difficult to design substantive rules applicable to the selection of a managing director, change of product design, or the decision to open a new plant. Although the American experience suggests that at least a certain range of decisions can be regulated by substantive rules at the local level, in Sweden there seems to be no intent or desire to do so.

Although the central codetermination agreements provide for supplementary local agreements, the contemplation seems to be that these too will be primarily procedural with few substantive rules or veto rights. What is contemplated is not participation through rules established in advance to govern future cases but negotiation of each case as it arises. The lack of rules does not necessarily mean less participation in the result but may mean only a more flexible problem-solving process.

The most striking characteristic of Swedish negotiations in this area, from an American point of view, is the unwillingness of Swedish unions to use the strike to restrict the employer's ultimate right to decide codetermination issues. The unions have not coupled negotiation of a codetermination agreement with negotiation of a wage agreement in order to use the threat of economic action on the two together. Section 44 of the Codetermination Act provides that the union, at the time of

15s The first proposal by the unions for a central codetermination agreement included a number of matters on which the union would have a power of decision, either in the form of deciding the matter in the first instance or having a veto right over the employer's decision. However, by the time of the union proposal of November 30, 1979, these matters had been dropped. 
making a wage agreement, can reserve the right to strike on codetermination issues free from the statutory peace obligation, allowing the union to strike on those issues separately during the contract term. The unions, however, have never asserted or used this surviving right to strike, even in the face of their inability over a period of five years to obtain a central codetermination agreement with the Employers Confederation. More important in the long run, the codetermination system as it is now being developed seems to contemplate that the unions' economic strength will not be used to influence the employers' decisions. Except for the unions' limited right to veto subcontracting under section 38, the employer will retain the right of final decision. The effectiveness of the employee's participation will be limited to the employer's willingness to listen and be persuaded.

In sharp contrast American unions regularly use the strike to influence the employer's decision on such matters. Wage issues and noneconomic issues are merged in negotiation; a strike will commonly involve both types of issues, and settlement of the strike may require employer concessions on both. Moreover, American unions are quite prepared to strike on noneconomic management prerogative issues. Indeed, such an issue is often the major issue and at times is the only issue.

The marked unwillingness of Swedish unions to use their economic strength to obtain codetermination agreements or influence decisions in this area invites speculation as to the reason. Perhaps the principal reason is that the unions have historically placed increased wages first and limitations on the employers' prerogatives last. ${ }^{154}$ In spite of the unions' emphatically stated demands for industrial democracy, the unions have not considered striking over it, particularly when the strike might lead to a nationwide shutdown. In addition, underneath there may be an intuitive sense, developed from seventy years of acceptance of paragraph 32, that the strike is not an appropriate instrument for asserting a share in the decisions of the enterprise. Such sharing should not be achieved or exercised by economic force, but by legislation or

154 See B. SCHILIER, supra note 43, at 79-80. Schiller states that those at the LO secretariat who worked with the enterprise democracy questions saw them as large and important questions, but "they were at the same time aware that compared with the wage questions they had low status in many persons' eyes. In a rank ordering of wages, work safety, job security and enterprise democracy, wages placed first and enterprise democracy last." Id. at 114. For a statement by the chairman of Svenska Industritjänstemännaförbundet (SIF) that the members of the union were not prepared to strike to obtain a joint regulation agreement, see TCO, KLARTEXT OM MEDBESTÄMMANDE: FRAN EN TCO-KONFERENS PA FORESTA 31 AUGUSTI 1981, at 17. 
negotiation. ${ }^{\mathbf{1 5 0}}$

We might conclude from the preceding discussion that the effectiveness of the employees' voice in influencing decisions on codetermination issues is much greater in the United States than in Sweden. In the United States, where collective bargaining exists, workers make their voice heard through persuasion backed by economic action; in Sweden, workers make their voice heard through persuasion alone. This bald description, however, may be misleading, for it ignores the willingness of employers in Sweden to listen to and accept the employees as partners in the enterprise. There is evidence that at least some Swedish employers, particularly larger ones, do not need the club of a strike to induce them to listen and give substantial weight to the employees' views in reaching decisions. Without any use of the strike or the threat of strike, a substantial number of codetermination agreements have been achieved in many enterprises since the passage of the statute. ${ }^{\mathbf{1 5 6}}$ The acceptance of unions and collective bargaining as a legitimate and essential part of society may give more reality to worker participation through persuasion in Sweden than is achieved through confrontation and strikes in the United States.

Because employees do not have enough votes to influence the outcome of management board decisions, employee representation on boards again provides employees with an opportunity to participate only through persuasion. Persuasion here has proven to be of limited effectiveness, and the primary value of board representation has been to provide the union with insight into the problems of the enterprise and

${ }^{163}$ Prior to negotiating the modification of the Basic Agreement in 1964-limiting the employer's right to discharge- LO stated that if negotiations with SAF did not give results, legislation would be necessary. B. ScHILLER, supra note 43 , at 76-77. In 1969 , when there was a proposal that paragraph 32 be taken up in the contract negotiations, the LO representative body rejected it. See $i d$. at 96 .

${ }^{106}$ Many research projects are trying to measure the effectiveness of the MBL in its practical operation. Many of these are unpublished and some are ongoing. The conclusions drawn are hopelessly conflicting, depending on the enterprises studied and the standard against which success is to be measured. In some cases the outcome seems predetermined by the character of the inquiry or the predisposition of those doing the research.

My net impression is that the process of consultation is working reasonably well in many larger enterprises and that the flow of information is quite substantial, even flooding the workplace representatives in some instances. In smaller enterprises the process is very uneven. It should be noted that when the statute became effective all the existing agreements on works councils and other forms of cooperation were terminated and local joint regulation agreements were barred, pending negotiation of a central joint regulation agreement with SAF, which was not reached until 1982. For five years joint regulation in all areas of the private sector, save banks and cooperatives, developed in this vacuum. The experience during this period was scarcely a fair measure of the potential effectiveness of the process after a central agreement was reached. 
with added information concerning its plans and activities. ${ }^{\mathbf{1 5 7}}$ This has allowed the union to increase its effectiveness in negotiations at the workplace under the Codetermination Act.

A separate and more effective avenue for participation in Sweden exists for matters concerning safety, health, and other elements of the working environment. Chapter 6 of the Work Environment Act of 1977 requires the naming of safety representatives in all work places of five or more employees and safety committees in workplaces of fifty or more employees. The safety representatives or committees have rights parallel to those of union representatives under the Godetermination Act: the right to participate in planning, the right to be notified before significant changes are to be made, and the right to all relevant information. They have, in addition, certain powers of decision. Where there is immediate and serious danger to life or health, they can order the suspension of work pending a decision by the Labor Inspectorate. The Central Working Environment Agreement ${ }^{158}$ between the employer and union confederations provides for joint safety committees, with employee representatives having the majority. This agreement has given employees greatly expanded decision-making powers in safety matters, including the approval of company doctors and safety engineers. In the United States no equivalent employee participation in safety matters is provided by law. Participation is through collective bargaining only, and, except in mining and the chemical industry, unions have made only limited efforts to include safety rules in their collective agreements. $^{159}$

\section{Participation by Employees in Employee Representation}

Participation by employees cannot be direct, except in matters affecting single workers or small groups. Participation must be through representatives, and in both Sweden and the United States that representative is the union. Measuring employee participation in decisions of the enterprise requires measuring employee participation in decisions of the union that represents them. Industrial democracy requires union democracy. We must therefore attempt to compare how much voice union members in Sweden and the United States have in the decisions of their unions.

To make this comparison it is again necessary to treat separately

157 See supra note 137.

168 See F. ScHMidT, supra note 4, at 150.

159 For some possible explanations why, see L. Bacow, Bargaining FOR JoB SAFETy AND Health 88-102 (1980). 
decisions concerning basic economic terms and decisions concerning other matters because, as the preceding section has pointed out, ${ }^{160}$ in Sweden these decisions are made by quite different processes and at different organizational levels.

Centralization of collective agreements in Sweden has removed decision-making so far from the union members that they have no effective voice in deciding the contents of the central agreement or even the national industry agreements that implement the central agreement. Members can only delegate to union officials three or four levels removed from them the authority to do what those officials believe is best. The members have no effective control through the election of those officials because they are selected through a multilayered union delegate structure that deadens any voice of disagreement. Their elections are seldom contested, and the principal officers are not required to run for re-election but are elected for indefinite terms-- "until further"--usually serving until retirement. ${ }^{101}$ Some unions have attempted to bridge this chasm between the members and those doing the negotiating by creating collective agreement conferences or advisory boards, but these add little to the members' actual participation in the decisionmaking process. At most they increase the likelihood that the decisions will be acceptable to the members. ${ }^{162}$

At one time, collective agreements were submitted to a membership vote, but in 1941 the Confederation of Labor's constitution was amended to require all national unions to provide in their statutes that the union's executive board had the authority to conclude the contract regardless of the vote. ${ }^{163}$ Even though the membership vote had been

160 See supra text accompanying notes 140-60.

101 In LO and the national unions, the officers, such as the chairman, vice chairman, secretary, and contract secretary, are elected "until further." The representative bodies, such as the Secretariat and Representantskapet, and national union board members are elected by the congress for the congress period.

162 Professor Lewin concludes, on the basis of answers to questionnaires, that the union leaders' opinions are representative of the members' opinions. He attributes this, in part, to the ability of the leaders to shape the members' opinions through active agitation and schooling and to some lack of respect for minority members' views. See $\mathrm{L}$. Lewin, Governing Trade Unions in Sweden 151-58 (1980).

Some of Professor Lewin's data indicate that there may be differences of opinion between the members and the leaders on such issues as wage and price freezes, $i d$. at 98-99 table 3.37, and collective affiliation, $i d$. at 85,89 table 3.26. A majority of members said one could justifiably accuse the steering committee of the national union and the top officials of LO of bossism, id. at 88 table 3.25, and that representatives are too influential compared with ordinary members, $i d$. at 89 table 3.26 .

${ }^{168}$ See J. WeSTERSTAHL, supra note 40, at 97. In most unions rejection of an agreement required a two-thirds vote of all those involved. Because many members did not vote, the officers were almost always able to sign the agreement even though a large majority of those voting had rejected it. 
only advisory, it was a form of participation through which the members could voice their dissatisfaction. It continued to be used until 1955 but with the coming of central negotiations even this advisory polling has been abandoned. ${ }^{164}$

The lack of membership participation in collective bargaining decisions is a nearly inevitable result of the nature of negotiations at a national level. As was pointed out earlier, centralization was itself a product of pressures from the Employers Confederation and the nature of the Confederation of Labor's wage policies. ${ }^{185}$ What is largely lacking is membership participation in the making of those wage policies except through the layered delegate structure of the unions, a structure that muffles and can distort their voice. A survey conducted in the early 1970's, for example, indicated that union members did not share the enthusiasm of district and national officials for the policies of wage solidarity and rationalization, ${ }^{168}$ yet it has been the district and national officials who have made these policies and implemented them in collective agreements.

Although employees have little or no voice in determining their wages and other economic terms at the central or industry level, they have an effective voice at the enterprise or workplace level. Here, grievances are settled, piece rates are negotiated, increases beyond those provided by the central agreement are obtained, and individual salaries for salaried employees are determined. ${ }^{167}$ This is done by the union club or other union workplace organization or by union representatives with whom the employees have personal contact. The employees' voice at this level is heard and is given weight.

In the United States the pattern and practice is quite different. ${ }^{168}$ This is in part because collective agreements are negotiated predominantly at the plant or enterprise level. Typically, the demands to be made in negotiations are compiled in a local membership meeting, the negotiating committee is made up of employees elected from the shop floor, and when a tentative agreement is reached, it is customarily submitted to a membership vote, which is binding. ${ }^{169}$ In about one out of

164 See A. HAdENIUS, supra note 61, at 171-80.

105 See supra text accompanying notes 37-43.

${ }^{168}$ L. LEWIN, supra note 162, at 72-77. For a more favorable view based on surveys made by LO, see Anderson, How Democratic Is The Swedish Trade UNION MOVEMENT? (1975).

167 See A. VICTORIN, supra note 70, at 127; S. EdLUND, supra note 71,; Törnblom, Medbestämmandelagen än paragraph 32 i modern skepnad, LAG \& AVTAL, Nov. 26, 1980.

${ }_{188}$ See generally Summers, Ratification of Agreements, in FrontIERs of CoLLECTIVE BARGAINING 75-102 (1967).

${ }^{168} I d$. at $80-81$. 
nine cases a tentative agreement is rejected, and there must be continued negotiations or a strike. ${ }^{170}$ Even when negotiations involve a large number of plants or employers, there may be a high level of participation. The auto workers, before opening negotiations with General Motors, may send questionnaires to members to obtain their views or ask each local union to make recommendations. Any agreement reached must be approved by a vote of all union members covered by the agreement. ${ }^{171}$ The steelworkers union has a wage policy committee, made up of representatives elected from local unions, that decides on demands and approves or disapproves settlements. ${ }^{172}$ The Teamsters National Master Freight Agreement is submitted to a referendum of the more than 300,000 members covered by the agreement.

It is safe to say that the union member's voice in this country's union decisions and policies on economic issues is much more direct and effective in the United States than in Sweden. The same cannot be said about noneconomic issues. As has been pointed out, the intention of the 1976 Act in Sweden was that employee representation on these issues was to be, in the first instance, by the workplace organization, where one existed, and otherwise by the section or local organization that usually was party to local negotiations. The union confederations have recognized that most of these decisions must be made at the local level, and the Employers Confederation declared in its proposal for a codetermination agreement that the decisions should be made "as near the [involved] employee as possible."173 These positions have been adopted by the codetermination agreement, which provides for a contact representative to be appointed by the local union organizations at every workplace. These decisions are thereby placed in the hands of representatives who are usually elected directly by the employees, will often be personally known to the employees, and are readily available. Although little research has been done concerning the internal processes of union clubs and other workshop organizations, these groups usually have several meetings a year, regular and open elections, and a frequent change of officers and committees, which prevents the development of an entrenched bureaucracy. ${ }^{174}$ This would seem to provide a most suitable situation for employees having an effective voice.

1701975 Lab. Rel. Y.B. (BNA) 39-40.

171 Summers, supra note 168 , at 80.

172 Id. at 79.

${ }^{173}$ MBA $\& 2$ (local and county governments).

174 See A. HAdENIUS, supra note 61, at 163. See generally HART, RIMFORS-JonSSON \& TEELAND, KLUBBSTYREISEN ORGanisation (1980). Where elections are not contested, it seems to be due primarily to the difficulty of finding individuals willing to serve. 
Union members in the United States may have somewhat less effective participation in the decisions of their union on these issues. Unionized plants are larger and collective agreements normally cover more employees than in Swedish workplaces, and as a result the employees' voice may be muffled by mere size. Where the collective agreement covers a large number of plants or is with an employers association, the employees' voice may be quite remote from the decision-making. Because all of these matters are negotiated together, along with wages, some will get little attention and some will be traded for other benefits. As a result, the voice of smaller groups of employees with special problems may be ignored. In the day-to-day administration of the agreement, the grievances of individuals or groups will be considered, but they will be bound by the substantive rules in the collective agreement. They may receive less satisfaction than if the agreement, as in Sweden, contained no substantive rules on the matter.

The most uncertain aspect of the above comparison is that the Codetermination Act has not yet been fully implemented and its impact on the internal structure of Swedish unions has not been fully felt. The comparison also assumes that the highly centralized unions will build a decentralized structure to carry out their functions under the Act. Thus it assumes a radical change in the unions' conception of their internal organizational structure. ${ }^{\mathbf{1 7 5}}$

Historically, a fundamental difference has existed between Swedish and American unions' conceptions of the democratic process. The Swedish conception has been expressed as one of representative democracy, with the emphasis on the representative exercising his knowledge and judgment on behalf of the members. The representative's responsibility is not to do what they claim is best, for it is not expected that they should tell their representative. The members do not participate in the decisions, rather they delegate the decision-making and rely on the representative's judgment.

American unions have relied much more on direct democracy, with the meeting of the local union being the prime forum for decision-making. ${ }^{178}$ Referenda are commonly used to ratify contracts, call strikes, increase dues, amend union constitutions, and elect national officers. Representative democracy has a different meaning, for the representative is expected to follow the will of his constituents. They participate

175 For recognition of this needed change, see TCO, SOM VI SER DET 58-63, $124-$ 26, 131-36 (1981); LO, 80-RAPPORTEN: RAPPORT TILL LO-KONGRESSEN 1981, at 162 (1981).

178 Periodic elections are so fundamental that when one union president was elected for life it was a national scandal, and he was described as "King Ryan." 
through him, as he speaks with their voice; he is their spokesman, not their decision-maker.

Much of the rhetoric that surrounded the passage of the Codetermination Act seemed to assume a conception of democracy much closer to the American model of participation than the Swedish model of representation, but there was no explicit discussion of what form the "enterprise democracy" should take. ${ }^{177}$ Whether the unions were aware at the time that participation at the enterprise or workplace level required a changed conception of democracy is not clear. But there is now a recognition that codetermination requires a decentralized union structure with decision-making at the local level and a disavowal of the traditional view of representation. For example, recognition of these changes is a recurrent theme in the Report of the 1981 Confederation of Labor Congress, which declared,

So, it is not enough either to say that democracy functions if the elected representatives reflect the electors' or the members' views. . . . Democracy functions fully first when the sharp boundary between elector/members and elected ceases to exist, when the whole collectivity conceives itself as participants in the same democratic process. ${ }^{178}$

If such declarations are given life in union structures and practices, the differences between Swedish and American unions' conceptions of how members are to participate in decisions of the union, particularly as to codetermination issues, will not be great.

In the United States the unions' historical commitment to democratic decision-making within the union, the traditional conception of the form the democratic process should take, is reflected and reinformed in legal rules. The Landrum-Griffin Act of $1959^{179}$ requires unions to

${ }^{177}$ For example, in Regeringens proposition 1975/76:9 it was said that the "fundamental idea in the committee proposal [was] that the employee should be given increased possibilities to influence the conditions in working life." LO declared that "the forms for influence must be such that one and all can become . . . participant[s]." Id. at 11. TCO placed equal emphasis on the "individual person's possibilities for influencing questions which are significant for her in the workplace." Id. at 12.

${ }_{178}$ LO, 80-RAPPORTEN: RAPPORT TILL LO-KONGRESSEN 1981, at 39 (1981). The Report also states,

A well functioning representative democracy assumes, however, that the member most directly involved has found some forum, for example, a club meeting, where he can go and make his voice heard, take part, and choose representatives, otherwise many are excluded from involvement and influence. TCO, SOM VI SER DET 126 (1981).

Id. at 128.

170 Labor Management Reporting and Disclosure Act of 1959, 29 U.S.C. $\S \S 401-$ 531 (1982). 
maintain certain minimum democratic standards, and these are conceived and articulated as parallel to the democratic standards expected of government, built on a participatory model.

Significantly, Title I of the Act is entitled "Bill of Rights of Members of Labor Organizations." The first right is that "Every member ... shall have equal rights and privileges . . . to nominate candidates, to vote in elections or referenda . . ., to attend membership meetings, and to participate in the deliberations and voting upon the business of such meetings." 180 It has been held to be a violation of this right for officers to refuse to allow members to raise an issue at a union meeting ${ }^{\mathbf{1 8 1}}$ or for the officers to sign a contract after it has been voted down by the members. ${ }^{182}$

The second right is entitled "Freedom of Speech and Assembly," and it protects "the right to meet and assemble freely with other members; and to express any views, arguments, or opinions; and to express at meetings ... [one's] views upon candidates in an election . . . or upon any business properly before the meeting." 183 This includes the right to criticize union officers and oppose union policies. For example, a member cannot be disciplined for claiming an officer had misused funds, even though the accusation is not proven. ${ }^{184}$ Nor can a member be punished because he argued that members should not pay dues, ${ }^{185}$ attended a meeting of fellow strikers and discussed the lack of progress in negotiating a settlement, ${ }^{186}$ or advocated legislation the union opposed. ${ }^{182}$ Debate concerning officers and policies within the union is to be open, vigorous, and unrestrained, with members participating actively both inside and outside union meetings. By such participation, union members are to make the decisions that affect them.

Title IV of the statute is designed to make the election of union officers an open competition, with the election campaign serving as a focus for debating union administration and policies. Electing for life or "until further" is prohibited; an incumbent officer must periodically

180 Id. $\S 411$. curiam).

181 See Parker v. Local Union No. 1466, 642 F.2d 104, 106 (5th Gir. 1981) (per

${ }_{182}$ See Alexander v. International Union of Operating Eng'rs, 624 F.2d 1235 (5th Cir. 1980).

18329 U.S.C. § 411(a)(2).

184 Salzhandler v. Caputo, 316 F.2d 445, 451 (2d Cir. 1963).

185 Farowitz v. Associated Musicians Local 802, 330 F.2d 999, 1002 (2d Cir. 1964).

${ }^{186}$ Kuebler v. Cleveland Lithographers and Photoengravers Union Local 24-P, 473 F.2d 359 (6th Cir. 1973).

${ }^{187}$ Mitchell v. International Ass'n of Machinists, 196 Cal. App. 2d 796, 807, 16 Cal. Rptr. 813, 819-20 (Gal. Dist. Ct. App. 1961). 
stand for re-election. ${ }^{188}$ Every member is guaranteed the right to make nominations and to campaign for a candidate. ${ }^{188}$ Candidates have a right to have their campaign literature distributed to all members, ${ }^{190}$ and no union money can be used to help elect a candidate. ${ }^{191}$ Thus the union newspaper or magazine cannot be used to favor the incumbent officers. ${ }^{192}$

Again, the conception here is one of an open political contest in which the members will actively participate and have a free choice. Elections are often hotly contested and incumbents are defeated, particularly at the local level. Even in the national unions, incumbent officers have been defeated in the Steelworkers, Rubber Workers, Electrical Workers, Mine Workers, Teachers, Municipal Employees, Post Office Employees and a number of other unions.

There is no equivalent statute in Sweden, and there are almost no court decisions on the legal rights of union members. ${ }^{193}$ The reason is quite evident-there has not been evidence of corruption, oppression, or abuse of power by union officers such as that which provoked legislation in the United States. This is true even though the centralization of Swedish unions, the lack of periodic elections, and the near absence of opposition groups in the union would appear to provide greater potential for such abuses. This raises the question why there is such a difference between unions in the two countries. One important factor is that Swedish unions have more deeply rooted traditions of political idealism and consider themselves participants in a social movement rather than organizations devoted to benefiting only their members' interests. Social welfare unionism in Sweden emphasized the union leaders' social responsibility whereas "business unionism" provided a hospitable climate for exploitation of leadership for self-aggrandizement.

\section{A Concluding Observation}

The most crucial contrast between Swedish and American labor relations is the difference in underlying attitudes of employers and unions toward each other. In Sweden employers and unions have historically accepted each other as social partners and viewed collective bargaining as a collaborative process of developing mutually acceptable

18829 U.S.C. $\S 481(a)$.

180 Id. § 481(e).

190 Id. $\$ 481(\mathrm{c})$.

191 Id. $\S 481(\mathrm{~g})$.

182 Yablonski v. UMWA, 305 F. Supp. 868, 875, order clarified, 305 F. Supp.

876 (D.D.C. 1969).

${ }^{193}$ See F. ScHMIDT, supra note 4, at 45-61. 
and socially responsible solutions. In the United States unions and employers have historically viewed each other as antagonists, with employers denouncing unionization and opposing collective bargaining. Negotiations, when they occur, are viewed as confrontations between hostile forces prepared to do economic battle.

One of the correlatives of this basic difference in employer-union relations was the difference in the unions' acceptance of management prerogatives. Swedish employers accepted collective bargaining because Swedish unions, through the December Compromise of 1906, accepted paragraph 32; American employers bitterly resisted collective bargaining, in part because American unions insisted on limiting the employer's freedom to manage the enterprise. Collaboration in Sweden was possible because there was an agreement between the two parties on what decisions were to be subject to joint control and what decisions were to be made by management. Confrontation in the United States was exacerbated because there was no such agreement to limit joint control.

Enactment of the Swedish Codetermination Act in 1976 undercut the premise on which collaboration had been based and injected into the Swedish system an attitude of confrontation typical of the American system. The political slogan was "Away with Paragraph 32," and, symbolically, section 32 of the statute directly repudiated paragraph 32 by providing that "there should, if the employee party so requests, also be concluded a collective agreement on a right of joint regulation" upon a nearly unlimited range of management decisions. ${ }^{184}$ All of these matters were opened up for collective negotiations, with ultimate resolution to be by strike, if necessary. Section 44 of the statute even preserves a special right to strike on these issues during the contract term. The statute has thereby created a battleground encompassing much more territory and reaching even more sensitive issues than identification of mandatory subjects of bargaining in the United States.

For an American, what followed was not surprising. Negotiation of a central codetermination agreement in the private sector came to repeated impasses. The tone of public debate between unions and employers hardened, and what was said in private was even harsher. The parties who had long engaged in joint labor market research could not even agree on what research was needed or how it should be conducted. Wage negotiations became more difficult, culminating in the great conflict of 1980 , and fears were expressed about the future of the "Swedish

184 MBL § 32, translated in F. SCHMIDT, supra note 4, at 239. 
Model."195 As in the United States, the dispute over the power to make decisions concerning management of the enterprise inflamed the whole union-employer relationship; confrontation on managerial control generated confrontation on all issues.

This comparative perspective raises a fundamental question concerning worker participation. Is it possible to have a system of collaborative collective bargaining in which employers accept unions as social partners and permit significant worker participation in the decisions of the enterprise? Both Swedish and American experience demonstrate that employers do not readily surrender or share the power of final decision in managing the enterprise. Is it possible for workers to obtain an effective voice in those decisions without creating a climate of confrontation in the union-management relation?

There are signs of what the Swedish solution may be, for the confrontation may be only temporary. The 1976 codetermination statute, built on the historical commitment and confidence in collective negotiation, has not of its own force changed the locus of power to decide. It only requires the employer to negotiate before making decisions; after negotiating, the employer still has the power to decide. Section 32 of the statute calls on employers to negotiate codetermination agreements, but it neither requires such an agreement nor requires that the agreement give the union or the employees the power to decide or veto any decision. Who should have the power to decide or veto is to be decided by agreement after negotiation.

The statute authorizes unions to use the strike to achieve an agreement, giving employees the power to decide or veto, but the unions have not used the strike and apparently do not intend to use it. Instead, they are prepared to settle for codetermination agreements that provide structures and procedures for negotiation. The ultimate right to decide will remain with the employer. With such an agreement, the inflammatory and divisive question of who shall decide is resolved, for it leaves the ultimate decision-making power where it has been for seventy-five years.

Such a resolution is acceptable to unions only because there is an assumption that negotiations on these issues will not be futile gestures-that employers will not exploit their power, but will shape their decisions through negotiation with a goal of reaching agreement. The law requires, and employers accept, that employees shall be fully informed concerning the financial condition, prospects, and plans of the

195 See Broström, Storkonflikten 1980, in STORKONFLIKTEN 1980, supra note 41; Eliasson, Om den svenska modellen, in STORKONFLIKTEN 1980, supra note 141, at 2629. 
enterprise and that employers are prepared to negotiate concerning the full range of managerial decisions. While retaining in principle the ultimate right of decision, the employer accepts its employees as full social partners in the enterprise. The unions, while insisting on the right to participate, are willing to rely on the negotiation process and the readiness of employers to agree rather than on the use of economic force. If unions and employers accept this definition of their relative roles in the decision-making process, there may be a basis for collaboration with participation, and the spirit of harmony and cooperation may re-emerge in the labor market.

The Swedish solution sharpens our awareness of the obstacles to the development of an American solution. We do not have the historical commitment to and confidence in collective negotiations as a means of arriving at mutually agreeable results. The deeply ingrained attitude of confrontation, articulated as a legal doctrine, erodes any confidence of unions or employers that the other will not press its interests to the limits of its potential economic force.

The Wagner Act $^{196}$ proclaimed a national policy of encouraging the processes of collective bargaining, but the statute was enacted because employers did not accept such processes. Passage of the statute did not change the dominant employer attitude; most employers continue to resist collective bargaining, and few have an affirmative commitment to negotiation as a constructive process.

Unions, on the other hand, have historically insisted on participation in managerial decisions beyond those concerning wages and other economic terms, and they have regularly used economic force to achieve that participation. They have encountered employers who rejected participation as an encroachment on managerial prerogatives and who used the law to limit bargaining. American unions, products of this past, are understandably unwilling to rely on the process of negotiation without resort to economic force to achieve meaningful participation.

The adoption of the potential Swedish solution of participation without confrontation in the United States is unlikely. There are some limited sectors and scattered single employers by whom collective bargaining is fully accepted and whose unions have substantial participation rights. Reaching an accommodation between employee voice and management control is not beyond the reach of inventiveness in collective bargaining. The confrontation syndrome, however, is not likely to shrink; on the contrary, it is likely to grow with increased efforts by employers to eliminate union representation.

${ }^{196}$ National Labor Relations Act, 29 U.S.C. $§ \S 151-169$ (1982). 
The nearly insurmountable obstacle to achieving employee participation in the United States is that less than thirty percent of employees are covered by collective bargaining. Extension of union representation to any measurable portion of the other seventy percent could be achieved only over determined employer opposition, which is likely to produce not so much a process of negotiation toward mutually agreeable results as a process of maneuvering in preparation for the outbreak of hostilities.

There is little reason to believe that union representation will be extended in the United States; the tide runs heavily in the other direction. If employee participation in the United States is to be achieved, it may be necessary to supplement union representation by other forms of employee representation. Experience in Sweden indicates that employers are more willing to accept participation by their own employees than by union representatives from the outside. This parallels the willingness of German employers to accept participation through works councils elected by their own employees, but not through the union, which is viewed as an outsider. This would point to our devising a statutory system of employee representation for plants or enterprises where collective bargaining does not exist.

The existence of obvious political obstacles to legislation that would enable unions to extend organization or that would establish a statutory system of employee representation leads to a final observation. The Swedish Codetermination Act of 1976 expressed a strong public conviction that employees should have a voice in the decisions of the enterprise that affect their working life. It was a rejection of the sovereignty of management and a commitment to industrial democracy. The United States made a similar, though not as explicit, commitment to industrial democracy in the Wagner Act. That commitment, however, has not been sustained; it has been largely pushed aside, ignored, and now nearly forgotten. The Supreme Court decisions in NLRB $v$. Yeshiva University ${ }^{\mathbf{1 9 z}}$ and First National Maintenance Corp. $v$. $N L R B^{198}$ are symptomatic of current legal and social attitudes. It is fair to say that we give little more than lip service, if that, to bringing democracy to employees' working lives. Even unions have half-forgotten their mission. This is, perhaps, the most fundamental contrast between Sweden and the United States. 


$$
\text { . }
$$

